\title{
Seed addition facilitates eelgrass recovery in a coastal bay system
}

\author{
Robert J. Orth*, Kenneth A. Moore, Scott R. Marion, David J. Wilcox, \\ David B. Parrish
}

Virginia Institute of Marine Science, School of Marine Science, 1208 Greate Road, College of William and Mary, Gloucester Point, Virginia 23062, USA

\begin{abstract}
Eleven years of eelgrass Zostera marina seed additions conducted in a coastal bay system where $Z$. marina had not been reported since 1933 have resulted in rapid $Z$. marina expansion beyond the initially seeded plots. From 1999 through 2010, 37.8 million viable seeds were added to 369 individual plots ranging in size from 0.01 to 2 ha totaling 125.2 ha in 4 coastal bays. Subsequent expansion from these initial plots to approximately 1700 ha of bay bottom populated with Z. marina through 2010 is attributable to seed export from the original plots and subsequent generations of seedlings originating from those exports. Estimates of annual patch vegetative

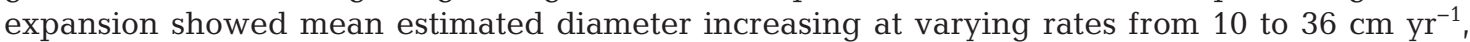
consistent with rhizome elongation rates reported for Z. marina. Water quality data collected over 7 yr by spatially intensive sampling, as well as fixed-location continuous monitoring, document conditions in all 4 bays that are adequate to support $Z$. marina growth. In particular, median chlorophyll levels for the entire sampling period were between 5 and $6 \mu \mathrm{g} \mathrm{l}^{-1}$ for each of the bays, and median turbidity levels, while exhibiting seasonal differences, were between 8 and 9 NTU. The recovery of $Z$. marina initiated in this coastal bay system may be unique in seagrass recovery studies because of how the recovery was initiated (seeds rather than adult plants), how rapidly it occurred (years rather than decades), and the explicit demonstration of how one meadow modulated water clarity and altered sediments as it developed and expanded. Our results offer a new perspective on the role seeds can play in recovery dynamics at large spatial scales.
\end{abstract}

KEY WORDS: Seeds · Germination · Seedling establishment · Zostera marina $\cdot$ Virginia coastal bays Resale or republication not permitted without written consent of the publisher

\section{INTRODUCTION}

Seagrasses are in decline worldwide as a result of human perturbations, most notably declining water quality (Orth et al. 2006a). Global declines in seagrass abundance have accelerated, with rates of loss increasing from $<1 \% \mathrm{yr}^{-1}$ before 1940 to $5 \% \mathrm{yr}^{-1}$ after 1980 (Waycott et al. 2009). Efforts to restore seagrasses have been successful for some regions and species, but have generally failed to alter the declining trajectories (Fonseca et al. 1998, Paling et al. 2009, Waycott et al. 2009). Recently, the study of dispersal dynamics and in particular the role propagule supply plays in bed dynamics is improving our understanding of how seagrasses respond to change (Kendrick et al. 2012).

One of the most dramatic changes in a seagrass species in the last century was the rapid decline of populations of eelgrass Zostera marina across the North Atlantic basin in the 1930s (Rasmussen 1977). While the decline was attributed to the 'wasting disease' caused by Labyrinthula, environmental factors such as temperature changes during this period may have also played a significant role (Rasmussen 1977). Regardless of the cause, the distribution of $Z$. marina populations throughout the North Atlantic was sig- 
nificantly and rapidly altered (Cottam \& Munro 1954, Rasmussen 1977). Populations in regions with lower salinities appeared to be less affected, possibly as a result of the Labyrinthula's intolerance to reduced salinities (Pokorny 1967). These unaffected populations apparently provided a propagule source for recovery of $Z$. marina in many locations. In one of the first extensive surveys of $Z$. marina populations along the Atlantic Coast of North America, Cottam \& Munro (1954) noted significant improvement in many, but not all, populations by the early 1950s, commenting that recovery was complete or nearly complete in a few areas. In Chesapeake Bay, where aerial photography from 1937 documents low to moderate levels of $Z$. marina abundance throughout its range, full recovery was apparent within $30 \mathrm{yr}$ (Cottam \& Munro 1954, Orth \& Moore 1983, 1984).

In contrast, Zostera marina populations in many high-salinity coastal bays were more susceptible to complete elimination by the disease. The coastal bays of the Delmarva Peninsula, USA, comprise one such region that lost $Z$. marina. While the northern bays (e.g. Chincoteague, Sinepuxent, Isle of Wight, and Assawoman Bays) recovered, possibly due to $Z$. marina either being transplanted from Chesapeake Bay sources or from surviving stock in the 1 bay that did have some low-salinity areas (Orth et al. 2006b), no recovery was recorded in the southern bays (e.g. South, Cobb, Spider Crab, and Hog Island Bays) almost 7 decades after the 1930s demise (Orth et al. 2006b). There was no within-bay source of seeds, as all populations of $Z$. marina had been eliminated by 1933, and seed banks, which are transient, would have been depleted in a year (Harwell \& Orth 2002b, Jarvis \& Moore 2010). The coastal bays in this region are relatively isolated from the nearest populations of surviving $Z$. marina $75 \mathrm{~km}$ to the north in Chincoteague Bay, or $50 \mathrm{~km}$ around the southern end of the peninsula into Chesapeake Bay. There are no accurate estimates of the total area historically occupied by $Z$. marina in these southern bays, as aerial photographs were not available until 1937. However, records of substantial bay scallop Aequipectin irradians harvests from these beds until 1932 indicate broadly abundant $Z$. marina, as bay scallops are generally found in Z. marina (Thayer \& Stuart 1974, Orth et al. 2006b). In addition, anecdotal reports from residents, especially those that harvested bay scallops, suggest these bays had an abundance of $Z$. marina.

In 1997, 2 small (ca. $1 \mathrm{~m}^{2}$ ) patches of Zostera marina were discovered in South Bay, one of the southern coastal bays. The patches were of unknown origin, and their reproductive shoot density suggested they were at least $2 \mathrm{yr}$ old. Ground surveys at this time revealed no other patches in this region. In order to assess the suitability of this bay to support sustained $Z$. marina growth, we transplanted adult plants in 1998 in several small test plots near these patches, first in South Bay, and in subsequent years in Cobb, Spider Crab, and Hog Island Bays (Orth et al. 2006b). While the 2 patches were covered by sand from a migrating spit within a few years of discovery, survival of the test plots provided additional evidence that the region could sustain $Z$. marina. We subsequently began an attempt to restore $Z$. marina to the coastal lagoons with seeds. In 1999, we initiated large-scale $\left(>100 \mathrm{~m}^{2}\right.$ areas) seed introductions using millions of seeds starting in South Bay and in later years expanding to include a total of 4 adjacent sub-basins where the relative isolation from the nearest seed-producing beds may have historically resulted in rare, lowdensity seedling recruitment.

Our objectives in this paper were to (1) highlight the rapid rate of expansion of Zostera marina following seed additions in this coastal bay system; (2) demonstrate that the rapid spread documented by aerial mapping was attributable to seed dispersal from patches initially produced from our seed additions; (3) highlight water quality conditions that have allowed Z. marina to survive and spread, documented by data collected through both spatiallysampled and continuously-monitored techniques over $7 \mathrm{yr}$; and (4) evaluate how the expansion of $Z$. marina influenced water clarity and sediments.

\section{MATERIALS AND METHODS}

\section{Study sites}

Seed addition studies were conducted in 4 adjacent sub-basins along the lower Delmarva Peninsula: South Bay, Cobb Bay, Spider Crab Bay, and Hog Island Bay (Fig. 1). The coastal bays are part of the Virginia Coast Reserve Long-Term Ecological Research site. We initiated large-scale Zostera marina restoration with seeds in South Bay in 1999, Cobb Bay in 2001, Spider Crab Bay in 2003, and Hog Island Bay in 2006 following at least $1 \mathrm{yr}$ survival of test plots in each bay (Orth et al. 2006c). Water depths at the seeded sites ranged from approximately 0.9 to $1.6 \mathrm{~m}$ at Mean Low Water (MLW), and the tidal range was approximately $1.2 \mathrm{~m}$. 


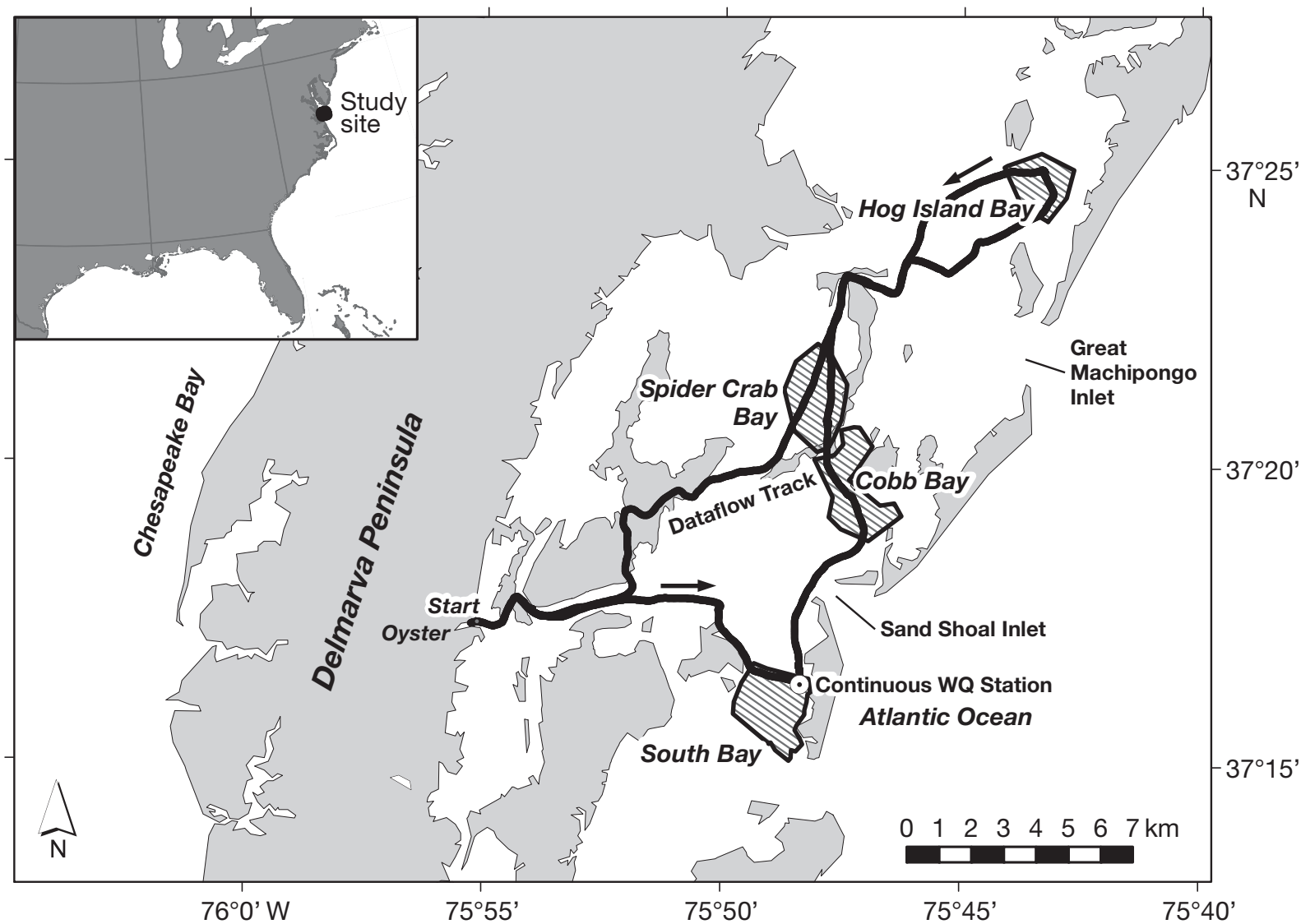

Fig. 1. Study region in the lower Virginia coastal bays, USA. Hatched polygons represent Zostera marina seed distribution regions. The solid line across all 4 bays represents the boat track for continuous underway water quality (WQ) sampling (Dataflow) cruises. The open circle in South Bay is the site of the continuous WQ monitoring station

\section{Seed collection and distribution}

Zostera marina flowering shoots with maturing seeds were harvested either by hand or by mechanical harvester in May/June and stored in aerated, flow-through tanks until seed release following procedures described by Marion \& Orth (2010a). Seeds were collected from Chesapeake Bay donor beds until 2007. After that time, we began collecting seeds from a 10 ha region of the expanding bed in South Bay. Seeds were separated from the senescing shoots and held in recirculating seawater tanks until distribution in October/November, just prior to the normal period of seed germination in this region (Moore et al. 1993). The proportion of viable seeds was determined just before distribution by individually assessing firmness and fall velocity of seeds in subsamples as detailed by Marion \& Orth (2010a). Batches of seeds with targeted numbers of viable seeds for individual restoration plots were measured volumetrically, and all seed numbers reported here refer to viable seeds.
Each fall from 1999 through 2010, Zostera marina seeds were hand broadcast from a boat into unvegetated plots. Fall broadcasting has been shown to maximize establishment rates (Marion \& Orth 2010a), partly by reducing losses to seed predators (Fishman \& Orth 1996). Plot size ranged from 0.01 to $2 \mathrm{ha}$, and seed density ranged from 6 to 1000 seeds $\mathrm{m}^{-2}$ (Table 1). A large majority of plots were either 0.2 or $0.4 \mathrm{ha}$, and were seeded at 25,37 , or 50 seeds $\mathrm{m}^{-2}$. In spring 2004, we deployed reproductive shoots holding developing seeds using an adaptation of the Buoy-Deployed Seeding method (Pickerell et al. 2005 ) into 0.8 to 2.0 ha plots in Spider Crab Bay. Plots distributed in different years were interspersed across each bay's suitable depth range (usually $<1.5 \mathrm{~m} \mathrm{MLW}$ ), allowing us to distinguish the relative effectiveness of different years' seedings and to compare the success of deep and shallow plots across years (McGlathery et al. 2012, this Theme Section). Seeded plots were separated by at least 60 to $100 \mathrm{~m}$ of unvegetated bottom, though patterns varied among bays and years. Additional small-scale seed experi- 
Table 1. Zostera marina. Summary of seed distributions for each of 4 coastal bays: number of viable seeds distributed $\left(\times 10^{6}\right)$, total area seeded (ha), plot size (ha) and number of plots seeded

\begin{tabular}{|c|c|c|c|c|c|c|c|c|c|c|c|c|c|c|c|c|}
\hline \multirow[t]{2}{*}{ Year } & \multirow{2}{*}{\multicolumn{4}{|c|}{$\begin{array}{l}\text { South Bay- } \\
\text { Seeds Area Plot size n plots }\end{array}$}} & \multirow{2}{*}{\multicolumn{4}{|c|}{$\begin{array}{c}\overline{\text { Cobb Bay }} \\
\text { Seeds Area Plot size n plots }\end{array}$}} & \multicolumn{4}{|c|}{${ }_{\text {Spider Crab Bay- }}$} & \multicolumn{4}{|c|}{$\ldots$ Hog Island Bay- } \\
\hline & & & & & & & & & Seeds & Area & Plot size & $\mathrm{n}$ plots & Seeds & Area & Plot size & n plots \\
\hline 1999 & 0.3 & 1.2 & 0.6 & 2 & - & - & - & - & - & - & - & - & - & - & - & - \\
\hline 2000 & 0.6 & 0.1 & 0.01 & 9 & - & - & - & - & - & - & - & - & - & - & - & - \\
\hline 2001 & 3.6 & 9.7 & 0.4 & 24 & 0.6 & 1.6 & 0.4 & 4 & - & - & - & - & - & - & - & - \\
\hline 2002 & 1.8 & 9.7 & 0.4 & 24 & - & - & - & - & - & - & - & - & - & - & - & - \\
\hline 2003 & - & - & - & - & 1.1 & 4.9 & 0.2 & 24 & 0.5 & 2.2 & 0.2 & 11 & - & - & - & - \\
\hline 2004 & 0.7 & 2.0 & 2.0 & 1 & - & - & - & - & 0.6 & 1.6 & 0.2 & 8 & - & - & - & - \\
\hline 2004 & - & - & - & - & - & - & - & - & 5.9 & 11.8 & $0.8-2.0^{\mathrm{a}}$ & 7 & - & - & - & - \\
\hline 2005 & 0.5 & 1.6 & 0.2 & 8 & - & - & - & - & 1.0 & 2.8 & 0.2 & 14 & - & - & - & - \\
\hline 2006 & - & - & - & - & - & - & - & - & 0.5 & 2.4 & 0.2 & 12 & 0.6 & 2.8 & 0.2 & 14 \\
\hline 2006 & - & - & - & - & - & - & - & - & - & - & - & - & 1.2 & 5.7 & 0.4 & 14 \\
\hline 2007 & - & - & - & - & - & - & - & - & 1.5 & 6.1 & 0.2 & 30 & 0.5 & 2.4 & 0.2 & 12 \\
\hline 2007 & - & - & - & - & - & - & - & - & - & - & - & - & 0.9 & 4.9 & 0.4 & 12 \\
\hline 2008 & - & - & - & - & - & - & - & - & 1.2 & 4.7 & 0.2 & 23 & 0.6 & 2.4 & 0.4 & 6 \\
\hline 2009 & - & - & - & - & 2.3 & 6.1 & 0.4 & 15 & 6.0 & 16.2 & 0.4 & 40 & - & - & - & - \\
\hline 2010 & - & - & - & - & - & - & - & - & 5.5 & 22.3 & 0.4 & 55 & - & - & - & - \\
\hline Total & 7.5 & 24.3 & - & 68 & 4.0 & 12.5 & - & 43 & 22.7 & 70.1 & - & 200 & 3.7 & 18.2 & - & 58 \\
\hline
\end{tabular}

ments covering 1 to $4 \mathrm{~m}^{2}$ were conducted in all 4 bays between 1999 and 2008, but these represented <1\% of the total seeds broadcast over the $11 \mathrm{yr}$ time period (Orth et al. 2003, Marion \& Orth 2010b, R. J. Orth unpubl. data). Plot sizes, numbers, and seeding densities used each year were generally determined by seed availability and the design of individual experiments conducted as part of the restoration effort (e.g. see McGlathery et al. 2012). From 1999 through 2010, 37.8 million viable $Z$. marina seeds were distributed into the 4 bays, with 7.5, 4.0, 22.7, and 3.7 million seeds distributed into total seeded areas of 24.3, 12.5, 70.1, and 18.2 ha in South Bay, Cobb Bay, Spider Crab Bay, and Hog Island Bay, respectively (Table 1).

Germination rates of seeds collected each year were estimated by planting replicate batches of either 10 or 20 seeds at approximately 5 to $7 \mathrm{~mm}$ depth in sandy sediments (generally $>95 \%$ sand and $<1 \%$ organic matter; Moore et al. 1993) in chilled, recirculating seawater inside a greenhouse. Water temperatures were adjusted to follow ambient water temperatures in the field. Germination was considered successful with the emergence of the cotyledon and first leaf.

Field assessment of seedling establishment was made in April, 6 mo after broadcast. Since seeds become rapidly incorporated into the sediment and do not move far from where they settle to the bottom (Orth et al. 1994), we were able to accurately assess establishment rates in seeded plots. Seeds typically germinate in early to late November in this region (Moore et al. 1993) and grow slowly during the winter months when water temperatures range from 0 to $5^{\circ} \mathrm{C}$. There is no evidence of a multi-year seed bank for Zostera marina in this region (Harwell \& Orth 2002a, Jarvis \& Moore 2010), and we assumed that no viable, ungerminated seeds from the previous year remained in the sediment by April. For large plots $\left(>100 \mathrm{~m}^{2}\right)$, seedlings were counted in $1 \mathrm{~m}$ line transects along the diagonals of each plot, and initial seedling establishment rates were calculated. Seedling establishment was assessed in smaller-scale experimental plots by complete counts of seedlings (Orth et al. 2003, Marion \& Orth 2010b, R. J. Orth unpubl. data). Data from both scales was used to assess seedling success for each bay.

\section{Eelgrass assessment}

Broad scale

Zostera marina bed areas were delineated from aerial photography acquired annually from 2001 through 2010, except for 2005. Black and white photography was acquired at a scale of 1:24 000 from an altitude of $3658 \mathrm{~m}$ with a mapping camera, following acquisition timing guidelines that optimize visibility of $Z$. marina beds (Orth et al. 2010). Acquisition timing rules specified tidal stage $( \pm 90 \mathrm{~min}$ of low tide), plant growth season (peak biomass), sun angle 
(between 20 and $40^{\circ}$ ), atmospheric transparency (cloud cover $<10 \%$ ), water turbidity (edge of grassbeds should be visible), and wind (less than 10 knots; Dobson et al. 1995). Images incorporated $60 \%$ flightline overlap and $20 \%$ side lap. Two flight lines were flown each year covering all shorelines and adjacent shoal areas of the 4 bays where the seed addition work was conducted. Aerial photography was scanned from negatives at a $1 \mathrm{~m}$ resolution and orthorectified using ERDAS LPS image-processing software. Z. marina bed boundaries were then directly photo-interpreted on-screen while maintaining a fixed scale using ESRI ArcMap GIS software (Orth et al. 2010). $Z$. marina beds were categorized as very sparse (1-10\% cover), sparse (10-40\% cover), moderate $(40-70 \%$ cover $)$, or dense $(70-100 \%$ cover $)$ based on a visual estimate of the percent cover on the photograph (Orth et al. 2010). For broad-scale distribution assessments in this study, we collapsed the 4 categories into 2: very sparse to sparse (1-40\%) and moderate to dense (40-100\%). Ground surveys were conducted in the bays each year to confirm the occurrence of $Z$. marina identified in the photography within and outside the boundaries of the seeded plots.

\section{Patch scale}

Three studies were conducted at a finer spatial scale in order to document Zostera marina recovery at the level of individual eelgrass patches. The first 2 evaluated additional high-resolution imagery of the South Bay study site to document seedling spread along a photographic transect and vegetative growth by tracking patches within a fixed area, while the third study used field sampling to document the spatial spread of seedlings across large distances outside of seeded plots.

The first study focused on a photographic transect, a $10 \times 280 \mathrm{~m}$ region in South Bay selected to document the rate of spread of Zostera marina from seeded plots into the nearby unvegetated area. The transect started along a linear plot seeded in 1999 and extended westward where no seagrass had been identified. High-resolution imagery was acquired for South Bay from 2001 to 2009 with 3 different imaging systems, all following the acquisition guidelines detailed above but flown at lower altitudes. Natural color aerial photography was acquired and scanned with a $7 \mathrm{~cm}$ resolution in June 2001, November 2003, and November 2004. Four-band multispectral imagery with a $30 \mathrm{~cm}$ resolution was captured in November 2003. Natural color digital imagery with a
$15 \mathrm{~cm}$ resolution was captured in December 2006, June 2007, January 2008, June 2008, February 2009, and December 2009. This resolution allowed us to follow the development of individual patches emerging from seedlings that originated from the nearby seeded plots. For each year that the higher-resolution imagery was available, the images were visually analyzed along the transect, and $Z$. marina cover within each $10 \mathrm{~m}$ section was classified using the 4 cover classes described above (very sparse, sparse, moderate, or dense). Potential nearby sources of $Z$. marina seeds included the 1999 plot at the eastern end, a 2001 plot $160 \mathrm{~m}$ to the SW, a 2002 plot $95 \mathrm{~m}$ to the NW, a 2005 plot $29 \mathrm{~m}$ to the N, and a 2005 plot $63 \mathrm{~m}$ to the $\mathrm{S}$.

We examined the role of vegetative growth in bed development in a separate, $67 \times 81 \mathrm{~m}$ study area that was more isolated from the directly seeded plots (200 m distant from a 2005 plot), allowing us to track the growth of individual patches without interference from additional nearby seedlings. We analyzed Zostera marina patches using 4 years of late fall/ winter high-resolution imagery (November 2004, December 2006, January 2008, and February 2009) where individual patches had not coalesced on the 2009 imagery. By late fall, Z. marina vegetative growth slows in this region, and patches generally persist through the winter with sparser cover than the mid-summer maximum due to typical latesummer senescence. This permits the use of photographs acquired during the relatively less turbid fall-winter conditions to assess the extent of patches during the preceding growing season (March through November). Z. marina patches were delineated using eCognition (Trimble GeoSpatial) object-oriented classification for each year. Patch polygons for all years were then merged across the years, following Wilcox et al. (2000), so that their growth history could be analyzed. Patches that did not persist were interpreted as ephemeral patches of macroalgae and eliminated from the analysis $(n=28)$, leaving 100 persistent patches. For each polygon, we measured the area and used the diameter of a circle of equal area as an estimate of the patch diameter to determine linear growth rates. This estimated diameter is slightly shorter than the actual patch maximum dimension since many patches were somewhat elongated, but provides a consistent linear metric for comparison of growth rates.

In addition to these 2 areas captured by aerial imagery, diver transects in 2006 were conducted to help assess the spread of Zostera marina across a broad zone in South Bay south of our targeted 
restoration plots. The 3 transects ( $1 \mathrm{~m}$ wide) were surveyed by divers in June 2006. The transects originated at edges of 0.4 ha plots established with seeds in 2002 and extended $650 \mathrm{~m}$ across regions where no seeds were broadcast. Divers recorded the presence or absence of $Z$. marina in every $1 \mathrm{~m}^{2}$ segment along each transect.

\section{Plant characteristics}

Reproductive output and bed characteristics were quantified in a region of restored Zostera marina in South Bay that had developed into a dense and continuous bed by 2006. Vegetative and reproductive shoot density was measured within $20 \mathrm{~cm}$ diameter rings haphazardly tossed by divers during the spring seed collection period in a portion of the bed in South Bay in early June each year from 2007 and 2010. The sampling spanned an area of approximately 10 ha, and coincided with the portion of the bed selected for seed collections in those years. In some years, the region was subdivided into sub-regions to examine spatial variability in shoot density and seed production. In addition, in 2009 and 2010, we assessed seed production by holding a representative sample of reproductive shoots in mesh bags in seawater tanks, and counting the number of viable seeds released.

\section{Sediments}

Sediment samples were collected from unvegetated areas in South Bay in 2000 and $2002(\mathrm{n}=12)$ when there was only limited, sparse vegetation in the larger region. Sediments were sampled again in the same general region in 2010 after South Bay became continuously vegetated $(n=10)$. Samples were taken using a $20 \mathrm{~cm}$ deep, $5 \mathrm{~cm}$ diameter tube. The top $2 \mathrm{~cm}$ of the sample were analyzed for percent sand, silt, clay fractions and total organic matter. Sand fractions (2000 to 62.5 microns) were analyzed by a rapid sediment analyzer, while silts and clays (<62.5 microns) were analyzed by the pipette method (Folk 1980). Total organic matter (percent ash free dry weight) was measured by drying and combusting a $10 \mathrm{~g}$ sample for $24 \mathrm{~h}$ at $550^{\circ} \mathrm{C}$.

\section{Water quality}

Two complementary approaches to documenting water quality conditions were undertaken. Broad spatial patterns in water quality were documented using continuous underway sampling (hereafter referred to as Dataflow) between 2003 and 2009. In addition, temporal patterns in water quality were documented through sensor deployments at 1 fixed station in South Bay.

The Dataflow cruise track (Fig. 1) traversed restoration areas in South Bay, Cobb Bay, Spider Crab Bay, and Hog Island Bay. Cruise tracks were expanded from the initial track in 2003 over South Bay as successive bays were added to the restoration effort. By 2005, the cruise track covered all 4 major bays and remained similar through 2009. Cruises were generally conducted monthly throughout the Zostera marina growing season, from March through November, although the total number of cruises varied annually (2003: 6; 2004: 4; 2005: 7; 2006: 8; 2007: 9 ; 2008: 9 ; 2009: 5). The length of cruise tracks in vegetated and unvegetated areas varied annually as the $Z$. marina beds developed and expanded. In South Bay in 2004, the cruise track (Fig. 1) was 0.7 and $1.2 \mathrm{~km}$ in the vegetated and unvegetated areas, respectively. In 2009 when the Z. marina bed had greatly expanded (see below), the length of the track was 1.5 and $0.40 \mathrm{~km}$ in the vegetated and unvegetated areas, respectively. The Dataflow sampling technique inherently caused some imbalances in the sampling size among the groups we analyzed (e.g. inside/outside beds) and between sampling dates, but not to the degree that would degrade the validity of our statistical comparisons.

The Dataflow underway sampler recorded in vivo measurements of surface water quality taken at 2 to $3 \mathrm{~s}$ intervals $(0.25 \mathrm{~m}$ depth below surface; approximately every $50 \mathrm{~m}$ ) along each cruise track. Measurements included turbidity, chlorophyll fluorescence, temperature, salinity, $\mathrm{pH}$, dissolved oxygen, GPS location, and depth using a YSI 6600 EDS sensor array (synchronized with a Garmin GPSMAP 169 Sounder). All sensors on the YSI 6600 EDS were both pre-cruise calibrated and post-cruise checked according to YSI standard procedures. In addition to the continuous underway sensor measurements, 8 calibration and verification stations were sampled at discrete locations spaced along each cruise track for total suspended solids (TSS), extracted pigment chlorophyll, and light attenuation profiles. TSS were determined by filtration of a known volume of seawater on pre-combusted Gelman, Type A/E filters, rinsing with fresh water, and drying at $60^{\circ} \mathrm{C}$. Chlorophyll a (chl a) was collected on Whatman GF/F glass fiber filters, extracted in a solvent mixture of acetone, dimethyl sulfoxide, and 1\% diethylamine (45:45:10 
by volume) and determined fluorometrically (Shoaf \& Lium 1976). Chlorophyll concentrations were uncorrected for phaeopigments. Chlorophyll fluorescence measurements were converted to extracted chlorophyll equivalents by developing a regression between extracted and fluoresced chlorophyll using the extracted chlorophyll and fluoresced samples taken simultaneously at each verification station for the entire study period. Diffuse downwelling attenuation of photosynthetically available radiation (PAR) was determined by triplicate water column measurements of downwelling photosynthetic photon flux density measured with a LI-COR, LIO-192, underwater cosine corrected sensor taken every $25 \mathrm{~cm}$ from $10 \mathrm{~cm}$ below the surface to $25 \mathrm{~cm}$ above the bottom. Similar to the YSI chlorophyll measurements, YSI turbidity measurements were converted to light attenuation equivalents using regression analysis relating turbidity to downwelling light attenuation coefficients $\left(K_{\mathrm{d}}\right)$ using all simultaneously measured light profiles and turbidities taken at the verification stations over the course of the study.

In order to capture temporally intensive water quality information at 1 site, a YSI 6600 EDS identical to that used in the Dataflow was deployed at a fixed monitoring station in South Bay (Fig. 1). Two-week deployments of the YSI sensor were undertaken at 2 mo intervals concurrent with every other Dataflow cruise. Water quality was measured $0.25 \mathrm{~m}$ above the bottom at $15 \mathrm{~min}$ intervals throughout each $2 \mathrm{wk}$ deployment. Four 2 to 3 wk sampling periods were conducted each year between 2003 and 2009, except 2003 and 2005 when only three 2 wk periods were assessed. In 2009, the YSI sensor was deployed continuously from 28 July through 18 December. Similarly, in 2010, the YSI was continuously deployed starting on 8 March and continued through the end of 2010. As with the Dataflow array, all sensors were pre-deployment calibrated and post-deployment checked for each deployment.

\section{Analyses}

Sediment data (percent organics and percent siltclay) from the period of sparse Zostera marina and the period of dense $Z$. marina were compared using $t$-tests. Spatial water quality was compared between vegetated and non-vegetated areas in each bay, within each bay over time, and among bays for each sampling year by first converting each spatial dataset to a congruent $10 \mathrm{~m}$ grid format using GIS. The grids were then combined to classify each year's Dataflow measurements according to permanent bay boundaries, and according to the year-specific $Z$. marina bed boundaries for each bay delineated from aerial photography (Fig. 1). Non-parametric Kruskal-Wallis rank sum tests were used to compare Dataflow measurements of water quality among bays, within bays over time, and between vegetated areas and nonvegetated areas within each bay using $R$ statistical software (R Foundation for Statistical Computing). Paired post hoc comparisons followed procedures originally published by Siegel \& Castellan (1988). Similarly, water quality measurements made at the fixed continuous-monitoring station in South Bay during the early summer deployment periods (when the $Z$. marina bed biomass and cover was typically the greatest annually) were compared among years using Kruskal-Wallis rank sum tests. Regression analysis was used to develop conversions between in vivo turbidity (nephelometric turbidity units, NTU) and underwater light attenuation $\left(K_{\mathrm{d}}=0.088 \times \mathrm{NTU}\right.$ $\left.+0.559 ; R^{2}=0.716\right)$, in vivo chlorophyll fluorescence and extracted chlorophyll (Extracted $\mathrm{chl}=1.386 \times$ In vivo chl $+1.765 ; \mathrm{R}^{2}=0.730$ ), and in vivo turbidity $(\mathrm{NTU})$ and TSS $\left(\mathrm{mg} \mathrm{l}^{-1}\right)\left(\mathrm{TSS}=2.592 \times \mathrm{NTU}_{;} \mathrm{R}^{2}=\right.$ 0.532) sampled simultaneously at each calibration and verification station sampling.

\section{RESULTS}

\section{Zostera marina seedling establishment}

Seeding was successful each year, but seedling establishment rates varied among individual plots, bays, and years (Fig. 2). The median seedling establishment rate for all 202 evaluated plots was $6.1 \%$, with median rates of $7.0,2.0,6.3$, and $6.4 \%$ recorded at South, Cobb, Spider Crab, and Hog Island Bays, respectively (Fig. 2). Laboratory germination rates of seeds previously assessed as viable were always greater than $80 \%$, confirming that the seeds we dispersed were largely viable seeds, and that differences between years in field seedling establishment were not explained by differences in viability of the seeds used.

\section{Meadow expansion and development}

Seed dispersal from plants in the restored plots to nearby unvegetated areas has resulted in an estimated 1714 ha containing Zostera marina by 2010 in these 4 bays, almost 14 times the originally seeded area. 


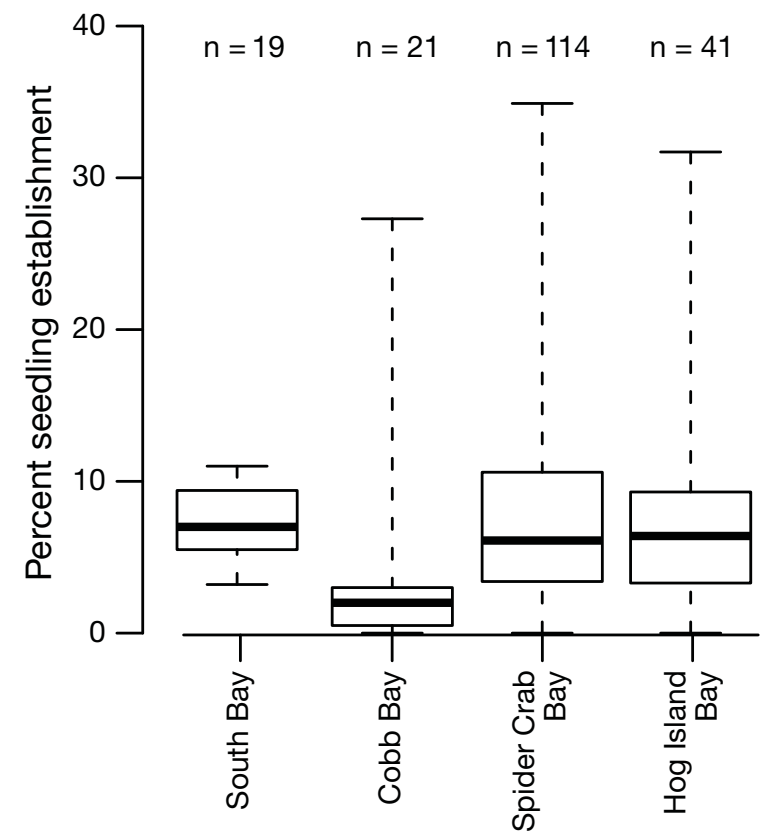

Fig. 2. Zostera marina. Seedling establishment rates observed across multiple years. Seedlings were assessed in April following seed distribution the previous fall

South Bay, where seeding began in 1999, showed the greatest spread and increase in coverage of the 4 bays. Eelgrass was first mapped for this bay in 2001, when 15.7 ha were recorded, all having sparse eelgrass cover (Fig. 3). This increased to $200 \mathrm{ha}$, also sparsely covered, in 2006. By 2010, 1020 ha were mapped, a $410 \%$ increase from 2006 , with $71 \%$ classified as moderate to dense cover. Aerial photographs from 2001 to 2010 show the rapid spread of Zostera marina in South Bay especially between 2006 and 2010 (Fig. 4).

Seed distribution in Cobb Bay began in 2001. Eelgrass was first mapped for this bay in 2003 when 3.9 ha, all sparse cover, were recorded (Fig. 3). By 2006, 41 ha were mapped with $11 \%$ considered moderate to dense cover. By 2010, Zostera marina coverage increased to 349 ha, with $27 \%$ classified as moderate to dense cover.

Seed distribution in Spider Crab Bay began in 2003. Eelgrass was first mapped in this bay in 2004 when only 0.3 ha, all sparse cover, was recorded (Fig. 3). In 2006, 1.6 ha were mapped as all sparse cover. By 2010, 163 ha were mapped, with 39\% considered moderate to dense cover.

Seed distribution in Hog Island Bay began in 2006. Eelgrass was first mapped in this bay in 2007 when 25.5 ha, all sparse cover, were recorded (Fig. 3). By 2010, 182 ha were mapped, with $52 \%$ considered moderate to dense cover.

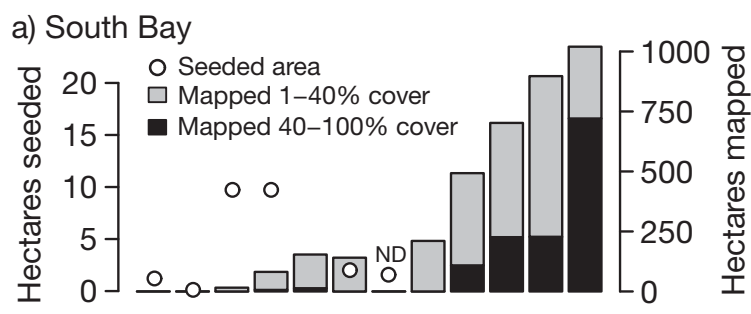

b) Cobb Bay

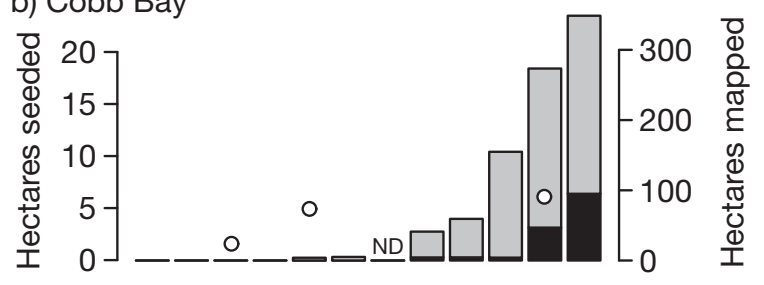

c) Spider Crab Bay
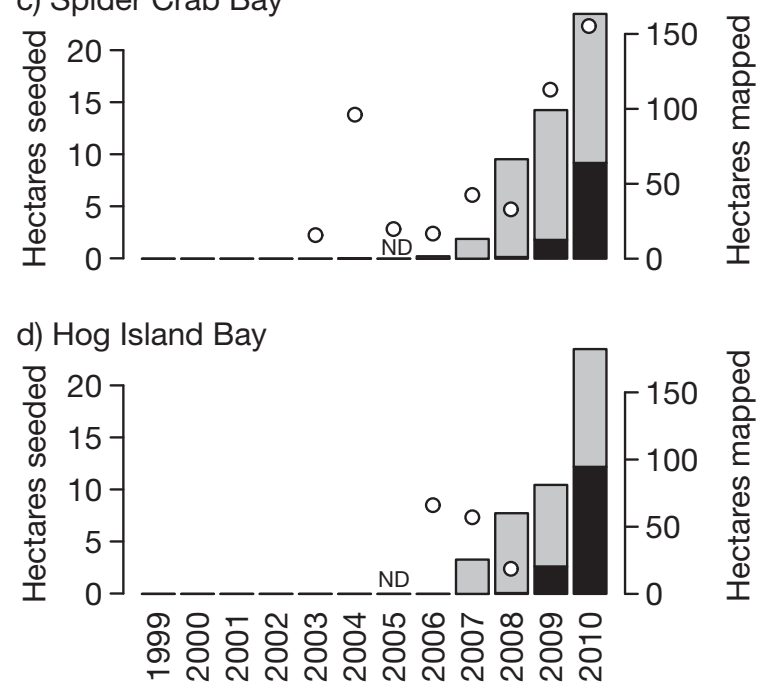

Fig. 3. Zostera marina. Area of seeding in each of 4 bays (circles, left $y$-axis), and area mapped in 2 density classes by aerial photography each year (bars, right $y$-axis). ND: no mapping data for 2005

\section{Patch-scale investigations}

The yearly photographic transect in South Bay documented a progression from a small number of eelgrass patches in 2001 to dense cover in 2009 (Fig. 5). In 2001, only 4 cells at the eastern end of the transect contained Zostera marina. By 2006, all cells had $Z$. marina, and the easternmost cell was dense. In 2009, all cells had at least sparse cover, and $64 \%$ of the transect had dense coverage.

The South Bay patch-tracking study area had Zostera marina patches that ranged in size from 0.03 to $3.85 \mathrm{~m}^{2}$ over the 4 photo acquisition dates (Table 2). The mean patch area for each cohort (patches first appearing on each of the 4 dates) 

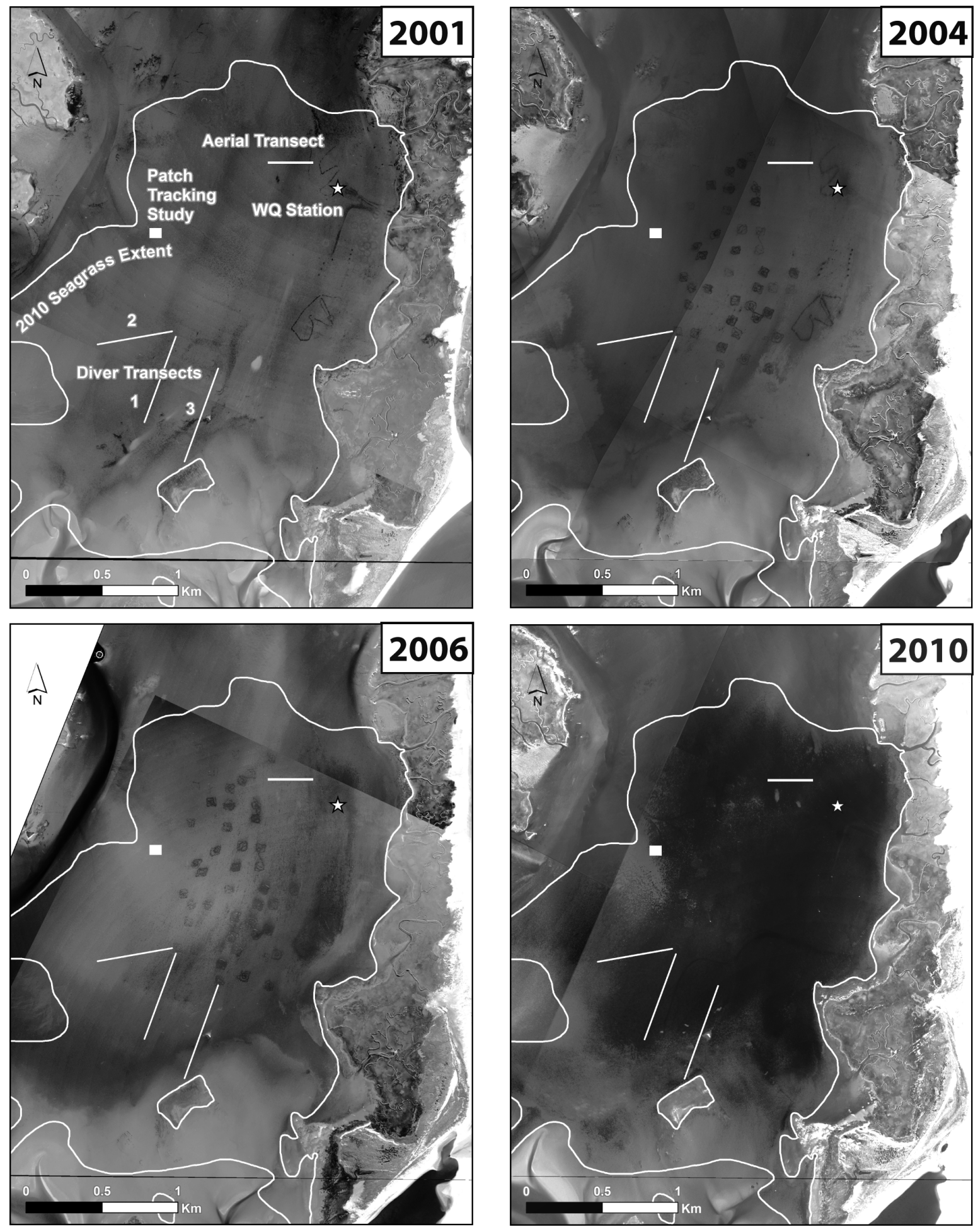

Fig. 4. Zostera marina. Aerial photo-mosaics from 2001, 2004, 2006, and 2010, showing meadow development in South Bay. Dark squares in the 2004 and 2006 photo-mosaic are the 0.4 ha seed plots from seed additions in 2001 and 2002 . These plots have coalesced and spread and the dark area in the 2010 photo-mosaic is one large continuous bed. The white line around the bed is the extent of the bed as mapped in 2010. Lines indicate a $280 \mathrm{~m}$ photographic transect where detailed analysis of aerial photography was conducted for 2001 to 2009, and the location of three $650 \mathrm{~m}$ diver transects conducted in 2006. Box indicates area where patches were tracked to study vegetative growth. Star indicates fixed-location water quality station. Linear artifacts are photographic boundaries within the mosaics 
increased in each subsequent observation (Table 2), with the mean estimated diameter increasing at varying rates from 10 to $36 \mathrm{~cm} \mathrm{yr}^{-1}$ (Table 3). Patch area totaled $15.45 \mathrm{~m}^{2}$ in November 2004 and expanded to $115.40 \mathrm{~m}^{2}$ in February 2009. The contribution of new patches to the total area on each subsequent date was $45 \%$ in December 2006, 29\% in January 2008, and $33 \%$ in February 2009. Analysis of imagery from December 2009 documents a dramatic increase to $2670.50 \mathrm{~m}^{2}$ for the entire area, compared to $140.79 \mathrm{~m}^{2}$ for the entire area in February 2009, including the 28 excluded patches.

The 2006 diver transects in South Bay (Fig. 4) showed Zostera marina presence for hundreds of meters outside the plots seeded in 2002 (Fig. 6). Careful inspection of aerial photography of the region acquired from 2001 and 2004 revealed that several small patches present in 2001 contributed to the spread of seedlings in this area, in combination with the directly seeded plots to the north. The origin of these plots is unknown, but their size in 2001 suggests they could have been second-generation seedlings originating from our early seed dispersals in 1999 and 2000 or from the initial 1998 and 1999 adult plant test plots.

\section{Plant characteristics}

Vegetative and reproductive shoot densities in South Bay varied among the years, with vegetative shoot densities decreasing from 2007 to 2010 (Table 4). Reproductive shoots also varied among years, repre-

Table 2. Zostera marina. Mean $\pm \mathrm{SD}$ area $\left(\mathrm{m}^{2}\right)$ of patches repeatedly measured from aerial photographs. Patches first observed on each date were each re-measured on subsequent dates

\begin{tabular}{|c|c|c|c|c|c|}
\hline $\begin{array}{l}\text { First } \\
\text { observed }\end{array}$ & $\begin{array}{c}\text { No. of } \\
\text { patches }\end{array}$ & Nov 2004 & Dec 2006 & Jan 2008 & Feb 2009 \\
\hline Nov 2004 & 11 & $0.12 \pm 0.10$ & $0.63 \pm 0.50$ & $0.99 \pm 0.54$ & $1.84 \pm 1.01$ \\
\hline Dec 2006 & 22 & & $0.39 \pm 0.29$ & $0.58 \pm 0.26$ & $1.33 \pm 0.56$ \\
\hline Jan 2008 & 35 & & & $0.38 \pm 0.19$ & $1.13 \pm 0.52$ \\
\hline Feb 2009 & 42 & & & & $0.90 \pm 0.47$ \\
\hline
\end{tabular}

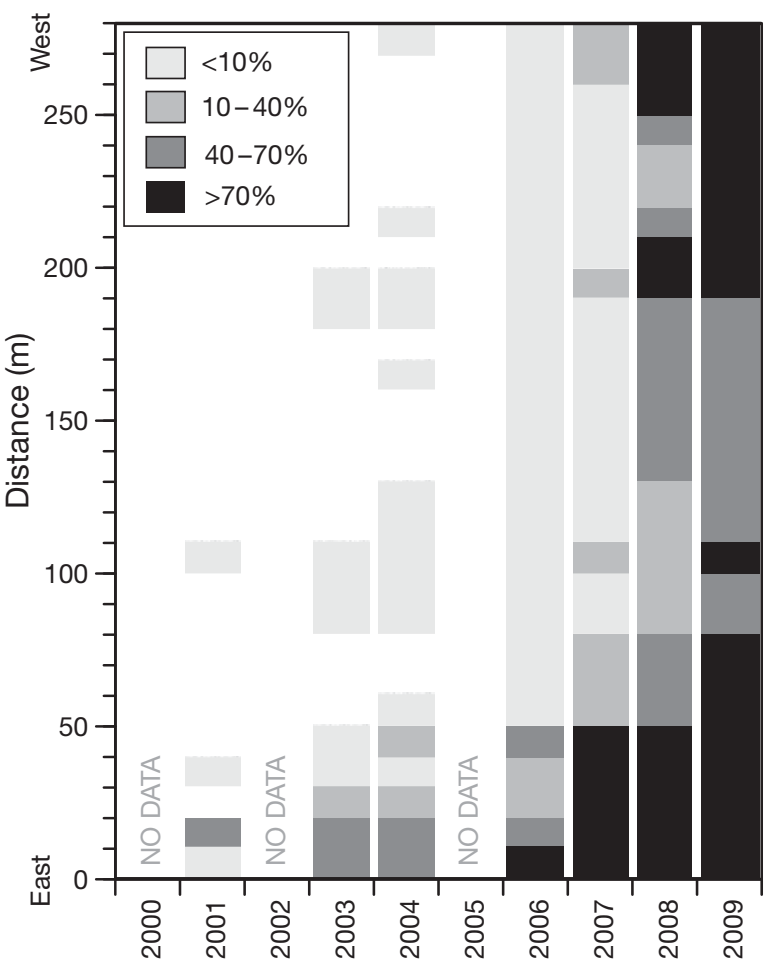

Fig. 5. Zostera marina. Changes in percent cover estimates in $10 \mathrm{~m}$ segments across a $280 \mathrm{~m}$ aerial photographic transect from 2001 to 2009

senting 8 to $41 \%$ of the total number of shoots. There was substantial spatial variation among sub-regions of the bed in vegetative and reproductive shoot density, despite very few perceived environmental gradients across the sampled region. Reproductive shoots sampled in 2009 and 2010 produced an average of 50 and 43 viable seeds shoot $^{-1}$, respectively.

\section{Sediments}

There was a significant increase in the percent silt-clay fraction and percent organics $(t$ tests, $\mathrm{p}<0.001$ ) from 2000 and 2002 when Zostera marina was very patchy to 2010 when

Table 3. Zostera marina. Mean \pm SD estimated diameter $(\mathrm{cm})$ and change from previous observation for patches repeatedly measured from aerial photographs on 4 dates. Estimated diameter is the diameter of a circle equal in area to the measured patch

\begin{tabular}{|lcccccccc|}
\hline First observed & No. of patches & Nov 2004 & Dec 2006 & Change & Jan 2008 & Change & Feb 2009 Change \\
\hline Nov 2004 & 11 & $21 \pm 08$ & $47 \pm 19$ & $27 \pm 19$ & $61 \pm 18$ & $14 \pm 18$ & $97 \pm 20$ & $36 \pm 20$ \\
Dec 2006 & 22 & & $37 \pm 13$ & & $47 \pm 12$ & $10 \pm 12$ & $79 \pm 14$ & $32 \pm 14$ \\
Jan 2008 & 35 & & & & $38 \pm 09$ & & $68 \pm 13$ & $30 \pm 13$ \\
Feb 2009 & 42 & & & & & $59 \pm 14$ \\
\hline
\end{tabular}




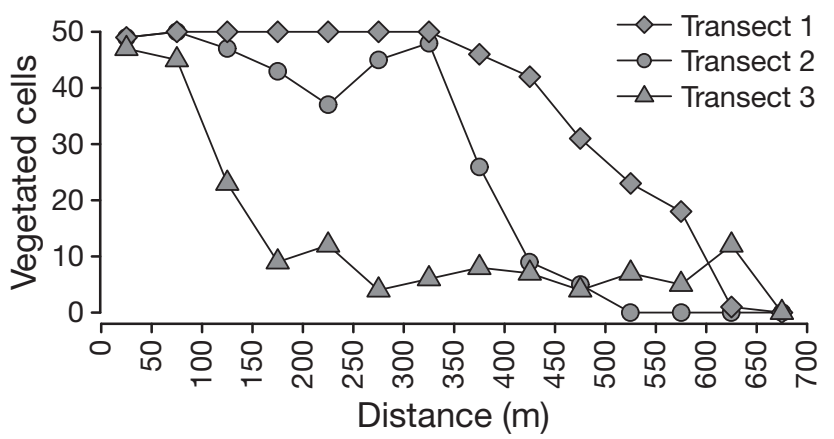

Fig. 6. Zostera marina. Diver observations of $Z$. marina presence in three $1 \times 650 \mathrm{~m}$ transects assessed in June 2006 . Data are the number of $1 \mathrm{~m}^{2}$ cells containing $Z$. marina within each $50 \mathrm{~m}$ transect segment. Transects started adjacent to 0.4 ha plots seeded in 2002 and extended to the southwest as indicated in Fig. 4

the bed had become dense and continuous (see photographs in Fig. 4). The mean silt-clay fraction more than doubled from $14.5 \pm 4.9(\mathrm{SD})$ to $34.6 \pm 4.4 \%$ while the organic content almost tripled from $1.0 \pm$ 0.2 to $2.8 \pm 0.4 \%$.

\section{Water quality}

Dataflow provided a characterization of each bay's conditions over short spatial scales as evidenced from 1 cruise in July 2009 (Fig. 7). Salinity demonstrated consistent levels among the various bay restoration sites, with concentrations typically within 1 to 2 PSU. Temperature, especially during the summer months, showed some variability, with lower summertime temperatures in the vicinity of the inlets. Dissolved oxygen and $\mathrm{pH}$ concentrations were generally lower near the western shore compared to the restoration

Table 4. Zostera marina. Mean \pm SD density of vegetative and reproductive shoots (no. $\mathrm{m}^{-2}$ ) assessed in early June between 2007 and 2010 in an area of South Bay with high percent cover. Multiple rows within years reflect sampling in sub-regions separated by 100 to $200 \mathrm{~m}$

\begin{tabular}{|cccc|}
\hline Year & n plots & Vegetative & Reproductive \\
\hline 2007 & 17 & $675 \pm 236$ & $471 \pm 111$ \\
2008 & 40 & $583 \pm 162$ & $51 \pm 38$ \\
& 40 & $497 \pm 194$ & $41 \pm 38$ \\
& 40 & $665 \pm 210$ & $76 \pm 60$ \\
2009 & 36 & $395 \pm 134$ & $73 \pm 51$ \\
& 30 & $707 \pm 264$ & $140 \pm 92$ \\
2010 & 30 & $337 \pm 108$ & $102 \pm 60$ \\
& 21 & $404 \pm 118$ & $54 \pm 32$ \\
& 42 & $395 \pm 115$ & $45 \pm 29$ \\
\hline
\end{tabular}

sites. Turbidity levels varied over short distances as much as 20 to $30 \mathrm{NTU}$, with higher levels near the channels, while chlorophyll levels usually varied by 5 to $10 \mu \mathrm{g} \mathrm{l}^{-1}$ across the transect.

Integrated monthly water quality conditions measured using Dataflow across each bay for all years combined (2003 to 2009) showed that salinities ranged between 28 and 34 PSU, with median levels between 31 and 32 PSU (Table 5). Temperatures during the March to November Zostera marina growing season ranged from $<5$ to $>25^{\circ} \mathrm{C}$ with medians near $20^{\circ} \mathrm{C}$ (Table 5). Dissolved oxygen was always high, with median levels between 7 and $8 \mathrm{mg} \mathrm{l}^{-1}$, while $\mathrm{pH}$ was well buffered at around 8.0 (Table 5). Turbidity levels were generally low, with median levels at 10 NTU or less (Table 5). Occasionally, high turbidity levels of up to 50 NTU were observed; however, approximately $75 \%$ of the time, turbidity levels were less than 15 NTU (K. A. Moore unpubl. data). Chlorophyll concentrations were also low, with median levels less than $6 \mu \mathrm{g} \mathrm{l}^{-1}$. The results show significant differences among the bays, although the differences are slight and the magnitude and direction of the differences are not consistent. Hog Island Bay had slightly lower median turbidity and slightly higher salinity, dissolved oxygen, $\mathrm{pH}$, and chlorophyll than the other 3 bays.

Integrated growing season turbidity levels for all cruises within each study year and bay showed significant yearly variation with 2005 demonstrating the highest turbidities across all bays (Table 6). Similarly, chlorophyll levels were highest in 2005, but no systematic temporal trends were observed across the $7 \mathrm{yr}$ time period for any of the bays (Table 7).

In South Bay, monthly variability in median turbidity for cruises from May to September (the time period with the most complete data) was observed, with lowest levels in May and September (Table 8). Turbidity levels within the vegetated areas were significantly lower than levels outside of the vegetated areas from June through September. Similarly, chlorophyll concentrations inside the beds were lower than levels outside the beds during July and August when chlorophyll concentrations were highest (Table 9).

Turbidity measurements obtained from the continuous monitoring station during deployments in the June to July periods each year when Zostera marina biomass was greatest demonstrated significant $(\mathrm{p}<$ 0.05 ) decreases over time (Fig. 8a). The median levels decreased from approximately 20 to $<5$ NTU, and the pulses of high turbidity also decreased over time, showing a consistent improvement in water clarity during this period of the growing season. 

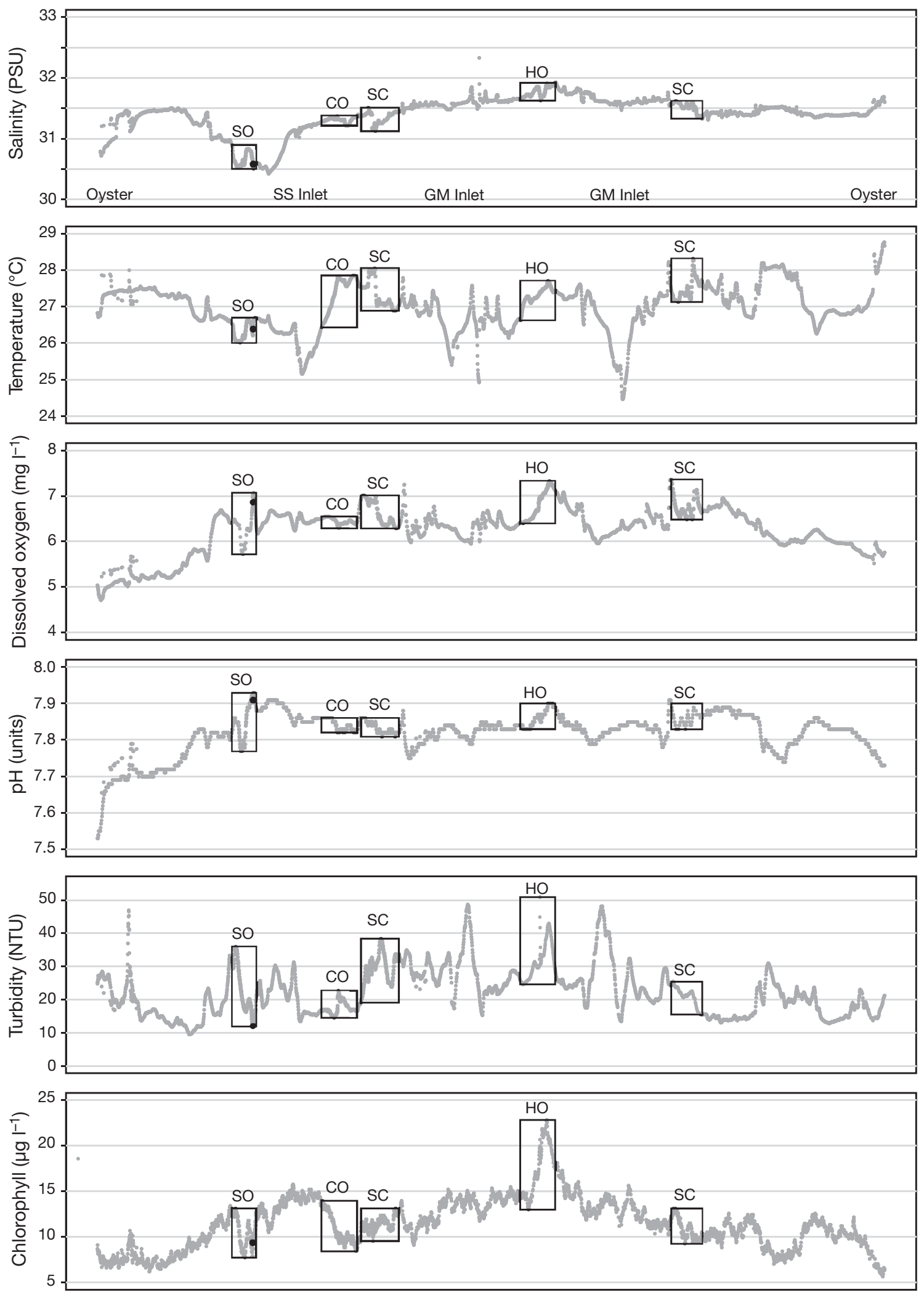

Fig. 7. Water quality parameters measured along the Dataflow track beginning and ending at Oyster, Virginia, as recorded on 28 July 2009. Boxes around data indicate the locations along the track of target restoration areas shown in Fig. 1. SO: South Bay, CO: Cobb Island, SC: Spider Crab Bay, HO: Hogg Island Bay, SS Inlet: Sand Shoal Inlet, GM Inlet: Great Machipongo Inlet. Black dot shows the South Bay continuous monitoring station 
Table 5. Median water quality parameters measured by Dataflow for all cruises combined (March through November, 2003 to 2009) within each bay. Identical superscripts indicate no significant differences in individual water quality parameters among the bays. DO: dissolved oxygen

\begin{tabular}{|lrrrr|}
\hline Parameter & Cobb & Hog & South & Spider \\
\hline Salinity (PSU) & $31.46^{\mathrm{a}}$ & $31.50^{\mathrm{b}}$ & $31.62^{\mathrm{c}}$ & $31.68^{\mathrm{a}}$ \\
Temperature $\left({ }^{\circ} \mathrm{C}\right)$ & $20.55^{\mathrm{a}}$ & $20.57^{\mathrm{b}}$ & $20.61^{\mathrm{b}}$ & $20.43^{\mathrm{c}}$ \\
DO (mg l $\left.{ }^{-1}\right)$ & $7.20^{\mathrm{a}}$ & $7.43^{\mathrm{b}}$ & $7.37^{\mathrm{c}}$ & $7.71^{\mathrm{d}}$ \\
pH (units) & $7.90^{\mathrm{a}}$ & $7.90^{\mathrm{b}}$ & $7.90^{\mathrm{c}}$ & $7.92^{\mathrm{a}}$ \\
Turbidity (NTU) & $9.93^{\mathrm{a}}$ & $9.94^{\mathrm{b}}$ & $9.49^{\mathrm{c}}$ & $8.02^{\mathrm{d}}$ \\
Chlorophyll $\left(\mu \mathrm{lg}^{-1}\right)$ & $5.37^{\mathrm{a}}$ & $5.51^{\mathrm{b}}$ & $5.64^{\mathrm{a}}$ & $5.06^{\mathrm{c}}$ \\
\hline
\end{tabular}

Table 6. Median turbidity (NTU) measured by Dataflow within each bay for March through November each year. Identical superscripts indicate no significant differences in turbidity among the years within each bay. ND: no data

\begin{tabular}{|lccccccc|}
\hline Bay & 2003 & 2004 & 2005 & 2006 & 2007 & 2008 & 2009 \\
\hline South & $9.90^{\mathrm{a}}$ & $7.80^{\mathrm{b}}$ & $16.90^{\mathrm{c}}$ & $13.30^{\mathrm{d}}$ & $8.20^{\mathrm{e}}$ & $9.30^{\mathrm{a}}$ & $12.05^{\mathrm{f}}$ \\
Cobb & $12.25^{\mathrm{a}}$ & $9.20^{\mathrm{b}}$ & $13.60^{\mathrm{c}}$ & $10.60^{\mathrm{d}}$ & $7.00^{\mathrm{e}}$ & $9.30^{\mathrm{a}}$ & $7.70^{\mathrm{d}}$ \\
Spider & $9.55^{\mathrm{a}}$ & $8.80^{\mathrm{a}}$ & $14.10^{\mathrm{b}}$ & $10.70^{\mathrm{a}}$ & $7.70^{\mathrm{c}}$ & $9.30^{\mathrm{a}}$ & $7.70^{\mathrm{a}}$ \\
Hog & ND & ND & ND & $11.41^{\mathrm{a}}$ & $5.20^{\mathrm{b}}$ & $8.50^{\mathrm{ac}}$ & $8.40^{\mathrm{c}}$ \\
\hline
\end{tabular}

Table 7. Median chlorophyll $\left(\mu \mathrm{g} \mathrm{l}^{-1}\right)$ measured by Dataflow within each bay for March through November each year. Identical superscripts indicate no significant differences in chlorophyll among the years within each bay. ND: no data

\begin{tabular}{|llllllll|}
\hline Bay & 2003 & 2004 & 2005 & 2006 & 2007 & 2008 & 2009 \\
\hline South & $3.84^{\mathrm{a}}$ & $4.81^{\mathrm{b}}$ & $6.89^{\mathrm{c}}$ & $6.20^{\mathrm{d}}$ & $5.79^{\mathrm{e}}$ & $5.09^{\mathrm{be}}$ & $5.23^{\mathrm{d}}$ \\
Cobb & $4.81^{\mathrm{a}}$ & $5.37^{\mathrm{b}}$ & $6.75^{\mathrm{c}}$ & $6.34^{\mathrm{b}}$ & $5.09^{\mathrm{a}}$ & $4.90^{\mathrm{d}}$ & $5.61^{\mathrm{b}}$ \\
Spider & $4.26^{\mathrm{a}}$ & $5.09^{\mathrm{bd}}$ & $6.86^{\mathrm{c}}$ & $5.79^{\mathrm{b}}$ & $5.51^{\mathrm{a}}$ & $5.23^{\mathrm{d}}$ & $5.65^{\mathrm{d}}$ \\
Hog & ND & ND & ND & $6.75^{\mathrm{a}}$ & $4.81^{\mathrm{b}}$ & $6.82^{\mathrm{a}}$ & $7.03^{\mathrm{a}}$ \\
\hline
\end{tabular}

Table 8. Median turbidity (NTU) measured by Dataflow inside and outside of Zostera marina beds in South Bay for all cruises combined (2003-2009) for each month. Identical superscripts indicate no significant differences in turbidity measured inside or outside of the vegetated areas for that month

\begin{tabular}{|lcc|}
\hline Month & Inside & Outside \\
\hline May & $7.24^{\mathrm{a}}$ & $7.5^{\mathrm{a}}$ \\
June & $10.6^{\mathrm{a}}$ & $14.6^{\mathrm{b}}$ \\
July & $15.6^{\mathrm{a}}$ & $24.5^{\mathrm{b}}$ \\
August & $13.5^{\mathrm{a}}$ & $13.8^{\mathrm{b}}$ \\
September & $8.1^{\mathrm{a}}$ & $10.7^{\mathrm{b}}$ \\
\hline
\end{tabular}

Table 9. Median chlorophyll measured by Dataflow inside and outside of Zostera marina beds areas in South Bay for all cruises combined (2003-2009) for each month. Identical superscripts indicate no significant differences in chlorophyll measured inside or outside of the vegetated areas for that month

\begin{tabular}{|lcc|}
\hline Month & Inside & Outside \\
\hline May & $4.67^{\mathrm{a}}$ & $4.26^{\mathrm{b}}$ \\
June & $5.51^{\mathrm{a}}$ & $5.65^{\mathrm{a}}$ \\
July & $8.97^{\mathrm{a}}$ & $9.25^{\mathrm{b}}$ \\
August & $8.14^{\mathrm{a}}$ & $8.56^{\mathrm{b}}$ \\
September & $6.34^{\mathrm{a}}$ & $7.03^{\mathrm{a}}$ \\
\hline
\end{tabular}

Chlorophyll levels measured at the continuous monitoring station demonstrated a pattern of significant $(p<0.05)$ decline over time (Fig. $8 b)$ similar to that observed for turbidity. A marked decline from the highest levels in 2003 was followed by a continuing decrease. Not only did the median levels decrease from approximately 17 to $<6 \mu \mathrm{g} \mathrm{l}^{-1}$, but the variability decreased markedly, especially the pulses of high chlorophyll.

\section{DISCUSSION}

Eleven years of Zostera marina seed additions conducted in 4 coastal bays where $Z$. marina had been absent since 1933 have resulted in the successful establishment and subsequent rapid expansion of $Z$. marina beyond the initially seeded plots. The success of this seeding in establishing expanding meadows in these 4 coastal bays suggests that seed supply was the recruitment bottleneck preventing re-establishment of $Z$. marina during its almost $70 \mathrm{yr}$ absence. The expansion in these bays outside the originally seeded plots is attributable to multiple generations of seedlings derived from the large number of seeds produced in and dispersed from these plots, rather than to vegetative growth from seeds we directly distributed. The development of these beds has influenced their ecosystems by altering sediment grain size, total organic matter, and water clarity.

\section{Zostera marina bed development}

The spatial and temporal patterns of change in Zostera marina we have observed in these coastal bays over the decade following initial seeding is a product of this species' reproductive phenology, seed production yields, dispersal mechanisms, and vege- 

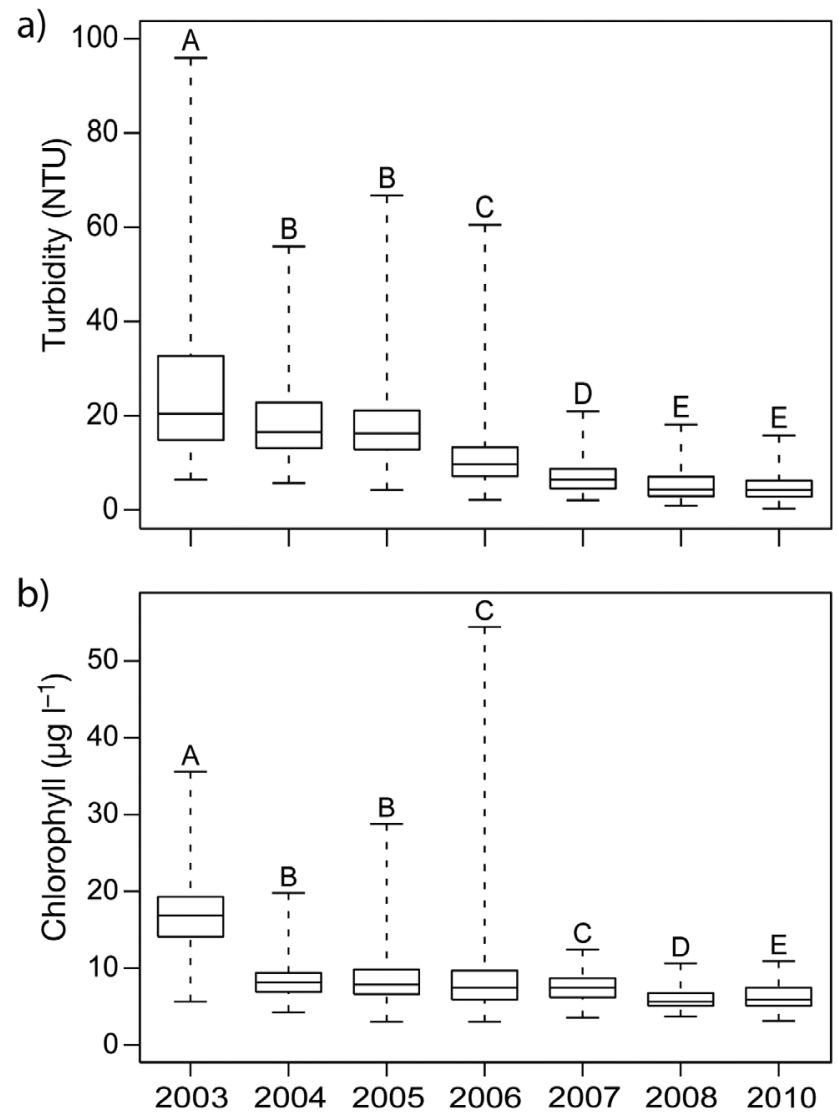

Fig. 8. (a) Turbidity and (b) chlorophyll (median, 25th and 75th percentiles, and the minimum and maximum of the lower $99 \%$ of the data). Data are from June and July from the South Bay monitoring station (see Fig. 1 for its location). Data are 15 min observations recorded during multiple $2 \mathrm{wk}$ deployments. Identical letters indicate no significant differences $(p<0.05)$ among medians

tative growth in our region. Seedlings in our region generally flower and produce seeds in their second year (Setchell 1929), and in each subsequent year. They add new recruits either close to the parent plant via floating seeds (Churchill et al. 1985) or distant from the meadow via buoyant flowering shoots with viable seeds (Harwell \& Orth 2002b, Källström et al. 2008). Flowering shoots, once they become negatively buoyant, are also transported along the bottom (Harwell \& Orth 2002b) and can be retained on benthic features, such as tubes of the onuphid polychaete Diopatra cuprea (Harwell \& Orth 2001), which are abundant in these bays. Once on the sediment surface, seeds are retained close to their settlement point by topographic complexities of the bottom (Orth et al. 1994) and are rapidly buried. These dispersal processes result in both outward expansion of the bed and increasing seedling density within the bed. Sparse patches developed and expanded outside the seeded plots from seeds generated by the initial plants within plots. Simultaneously, the seeded plots themselves became denser, not only by vegetative growth, but also by the production of seeds by newly developed reproductive shoots. These natural recruitment processes can be important for bed persistence, especially after diebacks due to stressful events such as unusually high summertime temperatures (Jarvis \& Moore 2010), high turbidity events due to phytoplankton blooms (Dennison et al. 1989), or storms (Williams 1988). We have discounted dispersal and establishment of vegetative fragments in developing new patches, as there is little evidence that these fragments can successfully establish (Ewanchuk \& Williams 1996, Di Carlo et al. 2005, Hall et al. 2006).

The relatively low rates of seedling establishment at 6 mo (medians of 2 to $7 \%$ of viable seeds distributed) in our unvegetated seed plots are largely a result of wintertime losses of early-stage, shallow seedlings which, without a substantial root system, are easily removed by wave action and currents that can erode sediments to several centimeters (Marion \& Orth 2012, this Theme Section). In addition, losses could have been exacerbated by drifting macroalgae which can dislodge newly emerging, or even well-developed, seedlings in less cohesive sediments (Valdemarsen et al. 2010). In the spring, we often observed uprooted seedlings anchored only by a few root hairs, and these seedlings sometimes had entangling masses of filamentous algae attached. This mechanism may help explain differences between years in seedling establishment as a product of different wind patterns and macroalgal abundances. The largest variability in seedling establishment was found between plots, but we did not attempt to correlate plot performance with plot-specific exposure to currents and wave action. Regardless, the within-year plot variability demonstrates that seed viability was not a substantial source of variation in seedling establishment in the restoration plots. Seedling establishment rates for seeds subsequently produced by patches we established are unknown, but would likely balance summer seed mortality, which we expect to be higher than for seeds stored in the lab, with potentially higher seedling retention rates due to physical protection provided by nearby pre-existing Zostera marina plants.

While we have highlighted the role seeds played in bed expansion rates, our estimates of patch vegetative expansion suggest that once a seed establishes, rhizome elongation is an important component in the early in-filling of the meadow. In our patch-expansion study area, the growth in estimated patch diameter 
from the low-level aerial imagery $(27 \mathrm{~cm}$ for $2 \mathrm{yr} ; 14$, $10,36,32$, and $30 \mathrm{~cm}$ for a single year; Table 3 ) is consistent with the $26 \mathrm{~cm}$ average annual rhizome elongation rates reported for Zostera marina (Marbà \& Duarte 1998). Areal spread of different cohorts of patches demonstrated variable growth rates, especially in their first year's growth $\left(0.12\right.$ to $\left.0.90 \mathrm{~m}^{2}\right)$ likely due to different environmental conditions between years. The longest-tracked patches attained an areal coverage of almost $3 \mathrm{~m}^{2}$ in $5 \mathrm{yr}$, illustrating the potential for vegetative growth to contribute substantially to internal meadow development through coalescence of adjacent seedling patches. However, by December 2009, the total area covered by new seedlings emerging in the unvegetated area between patches dwarfed the accumulated area resulting from vegetative growth of existing patches.

\section{Eelgrass effects on water quality and sediments}

Numerous studies have demonstrated the ability of seagrasses to influence their ecosystems by altering hydrodynamics and consequently sediment characteristics, increasing habitat complexity for fauna, altering predator-prey dynamics, or enhancing primary production (Larkum et al. 2006, van der Heide et al. 2011). The influence of eelgrass Zostera marina on 2 key characteristics, water quality and sediment composition, was documented in South Bay where $Z$. marina spread over the entire region by 2007. Water column turbidity was altered in South Bay between 2003 and 2010, with substantial reductions in both the range and the median value. There was a strong relationship between median June to July turbidity levels in South Bay and bed development (Fig. 9). Although these data are correlative, we regard the reduction in turbidity to be a consequence of the expanding bed, as similar reductions in turbidity over time were not seen in the other bays where $Z$. marina was much less extensive. This relationship is also consistent with our spatial comparisons of turbidity inside and outside of beds in all bays, which shows significantly lower turbidity within beds (Table 8). Median turbidities below 10 NTU were found only after the bed area exceeded 200 ha. At this point, bed expansion accelerated and turbidities continued to decrease to median levels of approximately 4 to 5 NTU in 2008 and 2010. In Chesapeake Bay, Moore (2004) found that the effects of $Z$. marina vegetation on water column suspended sediments, chlorophyll, and light attenuation increased with bed development. The effects of increasing $Z$. marina abundance on

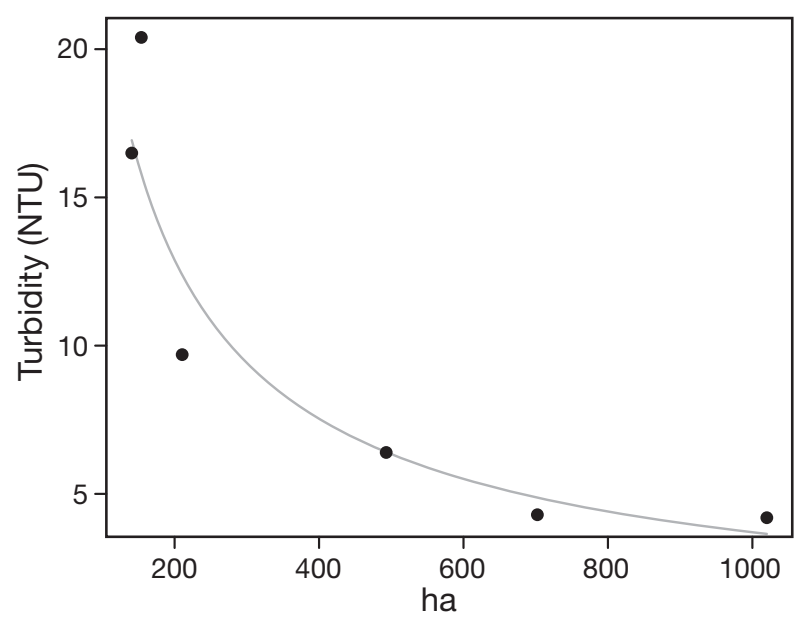

Fig. 9. Zostera marina. Relationship between yearly June to July South Bay median turbidity and yearly abundance (ha). The power regression function is $y=780.65 x^{-0.775}$, where $\mathrm{R}^{2}=0.9287$

suppressing resuspension and enhancing deposition that he observed were also apparent here, as both bed percent cover and area in the South Bay restoration site increased over time. One concurrent study in South Bay found near-bed mean velocity reduced by 70 to $90 \%$, and wave heights 45 to $70 \%$ compared to an adjacent unvegetated region shifting the seafloor from an erosional to depositional environment (Hansen \& Reidenbach 2012, this Theme Section). Similarly, chlorophyll concentrations also declined over time as the $Z$. marina beds developed, although the effects were not as consistent as with turbidity. In part this may be due to the relatively low levels of chlorophyll present in the bay even before the $Z$. marina expansion (see www1.vcrlter.virginia.edu/ home1/?q=data_wq), as well as other factors including South Bay's short residence time (Oertel 2001). The differences observed between the vegetated areas and adjacent unvegetated areas within these bays suggest that the $Z$. marina recovery has improved local water quality conditions.

Turbidities of 10 NTU were found to be equivalent to a light attenuation coefficient $\left(K_{\mathrm{d}}\right)$ of approximately $1.5 \mathrm{~m}^{-1}$ or approximately $22 \%$ of surface light reaching the bottom at a depth of $1 \mathrm{~m}$. In Chesapeake Bay, these light attenuation levels have been associated with shallow water areas where Zostera marina has been found growing to depths of $1 \mathrm{~m}$ at MLW or less (Dennison et al. 1993, Moore et al. 1996). Potentially stressful median June to July levels of $>10$ NTU were observed in the early years of the restoration project, but these summer levels decreased significantly in later years (Fig. 8a). Higher levels ( $>10$ to 15 NTU) have been found closer to the mainland 
(Fig. 7), where there is more effect of watershed loadings (Stanhope et al. 2009, Giordano et al. 2011) that contribute to the gradient of organic and inorganic constituents observed in the water column (Anderson et al. 2010). Higher turbidity levels were also found near the channels separating the different bays. These elevated levels may be caused by the local resuspension of sediments due to high currents or wave action in the channel areas. Previous field and modeling results of wind-driven sediment suspension and feedbacks on light availability in Hog Island Bay also show that $>60 \%$ of the bay may be suitable for Z. marina growth (Lawson et al. 2007).

Low water column chlorophyll levels were typical of the coastal bays throughout the entire study period, with concentrations typically below 5 to $10 \mu \mathrm{g} \mathrm{l}^{-1}$. Chlorophyll levels of $15 \mu \mathrm{g} \mathrm{l}^{-1}$ or greater have been associated with submersed aquatic vegetation (SAV) habitats that are under stress or in decline (Dennison et al. 1993). These low phytoplankton concentrations may be related to the short residence time of water within much of the eastern regions of these coastal lagoon areas (Oertel 2001).

Water quality conditions in the Virginia coastal bays studied here are largely related to the loadings that are affected by land use along the adjacent Delmarva Peninsula (Giordano et al. 2011). Here the watersheds are dominated by agriculture and forests, resulting in relatively low nutrient loadings (Anderson et al. 2010), in contrast to other coastal bays in Maryland and Delaware, where extensive development and intensive agriculture contribute to elevated loadings (Giordano et al. 2011) and enriched conditions (Boynton et al. 1996). Similarly, in coastal bay systems including Pamlico Sound, North Carolina, to the south, human activities have resulted in nutrient enrichment and sedimentation (Paerl et al. 2010), and in Barnegat Bay, New Jersey, to the north, increased loadings have been linked to seagrass declines (Kennish et al. 2010).

The percentages of silt-clay and total organics in the sediments increased significantly between 2002 and 2010. Because seagrass alters the hydrodynamic environment, with leaves baffling waves and currents, and roots and rhizomes stabilizing the sediments, fine-grained material is deposited and retained within the bed rather than remaining suspended in the water column (Ward et al. 1984, Koch 2001, Moore 2004, Koch et al. 2006, Gruber \& Kemp 2010). This increase in organic content in the sediments may provide increased nutrients for continued seagrass growth providing a positive feedback for continued bed development. Shoot densities in a portion of the South Bay meadow that had coalesced by 2007 generally declined from 2007 to 2010 despite sustained low turbidity. This potentially highlights the complex relationships between sediments and seagrass bed condition (Koch 2001), and indicates that further study on shoot dynamics is warranted as these beds develop over time.

\section{Restoration implications}

Our restoration effort over the course of $11 \mathrm{yr}$ used seeds rather than adult plants because of their availability in significant quantities annually (10s of millions per hectare), their ease of harvesting, and their adequate germination and establishment rates at our sites. Our seed distributions incorporated several different seed delivery techniques, seed densities, plot sizes, and plot configurations, an approach intended to allow optimization of future restoration efforts. Relative efficiencies of several seed collection and distribution techniques utilized here were discussed by Marion \& Orth (2010a), and detailed photographic analyses of plot performance relative to size, year, location, and seeding density are underway and are outside the scope of this paper. However, in general we found that plot size and seeding density were much less consequential to the eventual success of the restoration effort than simply the time allowed for subsequent generations of seedlings to spread from our initial distributions. Plots seeded at low densities (12 seeds $\mathrm{m}^{-2}$ ) remained very sparse for several years, but the eventual consolidation of plots occurred regardless of initial density. In addition, the sizes of our plots, though comparatively large as restoration plots, were much smaller than the distance across which seeds were exported. Therefore, for restoration at the scale of these coastal bays over a decadal time frame, the most important design considerations seem to be how widely the earliest plots are distributed across the landscape (determining how much total area will be within reach of subsequently exported seeds), and the number of seeds distributed (determining how many plants will initiate reproductive spread).

\section{CONCLUSIONS}

The successful re-establishment of Zostera marina in these 4 unvegetated coastal bays following the introduction of a large number of seeds suggests that propagule limitation may have been the ultimate factor that prevented $Z$. marina recovery following 
its disappearance in the 1930s, rather than a state change characterized by altered water quality conditions limiting re-growth (Peterson \& Lipcius 2003). While we do not have water quality data following the disappearance of $Z$. marina, anecdotal accounts during the period following the decline make no reference to possible changes in water quality. Given that water quality has shown no trends over the last 2 decades (see www1.vcrlter.virginia.edu/home1/ ?q=data_wq) in one of the coastal bay systems (Hog Island Bay), we suggest that water quality was likely not an impediment to recovery. While these bays are within the potential colonization distance of 2 source populations (Harwell \& Orth 2002a), the geography and isolation of these bays may have made seed delivery events rare. Currents along this coast flow from the north (Epifanio \& Garvine 2001), and Chincoteague Bay, the nearest northern source $75 \mathrm{~km}$ away, supported very little $Z$. marina until the 1990 s (Orth et al. 2006b). Recent genetic evidence from small natural patches of $Z$. marina observed in Hog Island Bay in 2004 linked these plants to Chincoteague Bay (Reynolds et al. 2012, this Theme Section, L. K. Reynolds unpubl. data). Given these genetic data, we believe the original patches we observed in South Bay in 1997 were also derived from Chincoteague Bay stock.

To illustrate the mechanism by which our seed additions facilitated the process of Zostera marina recovery, especially in South Bay, we present a simple synthetic model of the relationship we hypothesize between regional $Z$. marina abundance and seedling recruitment rate for an initially empty bay with suitable conditions for growth and reproduction (Fig. 10). A critical feature of the model is the rapid rise in seedling recruitment rate as the local population grows; this exponential increase results from subsequent generations of seedlings in turn flowering and releasing their own seeds. The effect of our seed additions was to mimic the seed production of a large local population, but at a stage of development with ample open space for seedlings to develop without competition from nearby adults. Placement of restoration plots across the extent of each targeted region helped accelerate the development of broadscale continuous coverage, compared with a strategy of concentrating recruitment in a core region that would later expand outward.

The 2 ends of the curve represent areas where additional research would be fruitful. The initial period of slow increase in recruitment rate is the result of limited seed production from early colonists and the time required for subsequent generations of

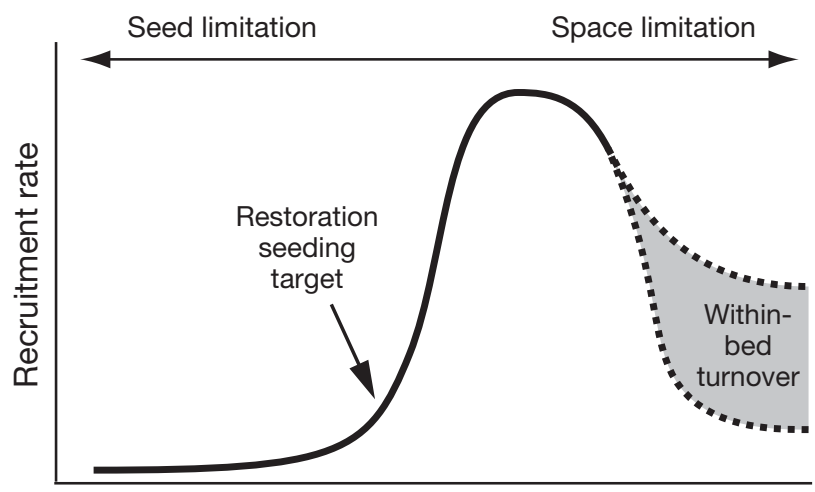

Regional Z. marina abundance

Fig. 10. Zostera marina. Hypothesized relationship of seedling recruitment rate to regional abundance

seedlings to spread across the region. However, an important question is whether additional factors may act to maintain low recruitment during this period. Such factors might include high seed predation on small numbers of seeds, disturbance of plants by foraging crabs or rays, macroalgal attachment causing the uprooting of isolated seedlings, and low pollination success for sparse, isolated plants. Our highdensity seed additions may have provided a critical number of seedlings to escape the constraints that might otherwise limit or kill natural colonists. The decrease in recruitment at the right end of the curve reflects limited seedling establishment within a highdensity bed of relatively continuous coverage. The actual scale of this reduction is poorly understood because seedling success rates are most easily documented in unvegetated sand, while their contribution to the maintenance of existing beds is not well understood (Olesen 1999), except in the case of recovery of gaps after a disturbance (Plus et al. 2003, Greve et al. 2005, Jarvis \& Moore 2010).

The recovery of Zostera marina initiated in this coastal bay system may be unique in seagrass recovery studies because of how the recovery was initiated (seeds rather than adult plants), how rapidly it occurred (years rather than decades), and the explicit demonstration of how one meadow modulated water clarity as it developed and expanded. The success we observed here was enabled by species traits (high seed yield, regional seed dispersal, adequate germination, and rapid vegetative growth) and site traits (semi-enclosed bays with suitable depth, bottom type, and water quality) that may be found in only certain species and regions. For example, Z. marina in the northeast United States may recover at a slower rate because of slower patch recruitment rates and slower vegetative growth (Neckles et al. 2005). 
Regardless of these potentially unique conditions our results offer a new perspective on the role seeds can play in recovery dynamics at large scales and may explain, in part, the rapid rate of recovery of $Z$. marina following its 1930s demise (Cottam \& Munro 1954) in areas that retained a regional source of seeds.

Acknowedgements. We acknowledge the contributions of numerous staff, students, and volunteers who have contributed to this project over the last decade. We especially thank B. Truitt of The Nature Conservancy for his continued support since the inception of this project and for sharing much of his local knowledge of this region. Their dedication, patience, and perseverance are greatly appreciated. Comments by 4 anonymous reviewers significantly enhanced the quality of the paper. Funding was provided by grants from numerous agencies, notably the Coastal Programs of the Virginia Department of Environmental Quality funded by Coastal Zone Management Act of 1972, as amended, administered by NOAA's Office of Ocean and Coastal Resource Management, the Virginia Recreational Fishing License Fund, the American Recovery and Reinvestment Act with funding from NOAA to The Nature Conservancy (Grant No. NA09NMF463038), U.S. Army Corps of Engineers, and Virginia Department of Transportation, as well as private grants from the Allied-Signal Foundation, Norfolk-Southern, the Volgenau Foundation, the Greater Hampton Roads Foundation and the Keith Campbell Foundation for the Environment. This is contribution no. 3193 from the Virginia Institute of Marine Science.

\section{LITERATURE CITED}

Anderson IA, Stanhope JW, Hardison AK, McGlathery KJ (2010) Sources and fates of nitrogen in Virginia coastal bays. In: Kennish MJ, Paerl, HW (eds) Coastal lagoons: critical habitats of environmental change. CRC Press, New York, NY, p 43-73

Boynton WR, Hagy JD, Murray L, Stokes C, Kemp WM (1996) A comparative analysis of eutrophication patterns in a temperate coastal lagoon. Estuaries 19:408-421

Churchill AC, Nieves G, Brenowitz AH (1985) Flotation and dispersal of eelgrass seeds by gas bubbles. Estuaries 8: 352-354

Cottam C, Munro DA (1954) Eelgrass status and environmental relations. J Wildl Manag 18:449-460

Dennison WC, Marshall WC, Wigand C (1989) Effect of 'brown tide' shading on eelgrass (Zostera marina) distributions. In: Cosper EM, Bricelj VM, Carpenter EJ (eds) Novel phytoplankton blooms: causes and impacts of recurrent brown tides and other unusual blooms. SpringerVerlag, New York, NY, p 675-692

Dennison WC, Orth RJ, Moore KA, Stevenson JC and others (1993) Assessing water quality with submersed aquatic vegetation. Bioscience 43:86-94

Di Carlo G, Badalamenti F, Jensen AC, Koch EW, Riggio S (2005) Colonisation process of vegetative fragments of Posidonia oceanica (L.) Delile on rubble mounds. Mar Biol 147:1261-1270

Dobson JE, Bright EA, Ferguson RL, Field DW and others (1995) NOAA coastal change analysis program (C-CAP): guidance for regional implementation. NOAA Tech Rep NMFS 123

Epifanio CE, Garvine RW (2001) Larval transport on the Atlantic continental shelf of North America: a review. Estuar Coast Shelf Sci 52:51-77

Ewanchuk PJ, Williams SL (1996) Survival and re-establishment of vegetative fragments of eelgrass (Zostera marina). Can J Bot 74:1584-1590

> Fishman JR, Orth RJ (1996) Effects of predation on Zostera marina seed abundance. J Exp Mar Biol Ecol 198:11-26

Folk RL (1980) Petrology of sedimentary rocks. Hemphill Publishing Company, Austin, TX

Fonseca MS, Kenworthy WJ, Thayer GW (1998) Guidelines for the conservation and restoration of seagrasses in the United States and adjacent waters. NOAA Coastal Ocean Program Decision Analysis Series No. 12. NOAA Coastal Ocean Office, Silver Spring, MD

> Giordano JCP, Brush MJ, Anderson IA (2011) Quantifying annual nitrogen loads to Virginia's coastal lagoons: sources and water quality response. Estuar Coasts 34: 297-309

Greve TM, Krause-Jensen D, Rasmussen MD, Christensen PB (2005) Means of rapid eelgrass (Zostera marina L.) recolonization in former dieback areas. Aquat Bot 76: 291-297

Gruber RK, Kemp WM (2010) Feedback effects in a coastal canopy-forming submersed plant bed. Limnol Oceanogr 55:2285-2298

Hall LM, Hanisak MD, Virnstein RW (2006) Fragments of the seagrasses Halodule wrightii and Halophila johnsonii as potential recruits in Indian River Lagoon, Florida. Mar Ecol Prog Ser 310:109-117

> Hansen JCR, Reidenbach MA (2012) Wave and tidally driven flows in eelgrass beds and their effect on sediment suspension. Mar Ecol Prog Ser 448:271-287

> Harwell MC, Orth RJ (2001) Influence of a tube-dwelling polychaete on the dispersal of fragmented reproductive shoots of eelgrass. Aquat Bot 70:1-8

Harwell MC, Orth RJ (2002a) Seed bank patterns in Chesapeake Bay Zostera marina L.: a baywide perspective. Estuaries 25:1196-1204

Harwell MC, Orth RJ (2002b) Long-distance dispersal potential in a marine macrophyte. Ecology 83:3319-3330

Jarvis JC, Moore KA (2010) The role of seedlings and seed bank viability in the recovery of Chesapeake Bay, USA, Zostera marina populations following a large-scale decline. Hydrobiologia 649:55-68

Källström B, Nyqvist A, Åberg P, Bodin M, Andre C (2008) Seed rafting as a dispersal strategy for eelgrass (Zostera marina). Aquat Bot 88:148-153

Kendrick GA, Waycott M, Carruthers T, Cambridge M and others (2012) Role of dispersal in the colonization, establishment, persistence and evolution of seagrasses. Bioscience 62:56-65

Kennish MJ, Haag SM, Sakowicz GP (2010) Seagrass decline in New Jersey coastal lagoons: a response to increasing eutrophication. In: Kennish MJ, Paerl HW (eds) Coastal lagoons: critical habitats of environmental change. CRC Press, New York, NY, p 167-202

Koch EW (2001) Beyond light: physical, geological and geochemical parameters as possible submersed aquatic vegetation habitat requirements. Estuaries 24:1-17

Koch EW, Ackerman JD, Verduin J, van Keulen M (2006) Fluid dynamics in seagrass ecology: from molecules to ecosystems. In: Larkum AWD, Orth RJ, Duarte CM (eds) Seagrasses: biology, ecology and conservation. Springer, Dordrecht, p 193-225 
Larkum AWD, Orth RJ, Duarte CM (eds) (2006) Seagrasses: biology, ecology and conservation. Springer, Dordrecht

Lawson SP, Wiberg PL, McGlathery KJ (2007) Wind-driven sediment suspension controls light availability in a shallow coastal lagoon. Estuar Coasts 30:102-112

- Marbà N, Duarte CM (1998) Rhizome elongation and seagrass clonal growth. Mar Ecol Prog Ser 174:269-280

Marion SR, Orth RJ (2010a) Innovative techniques for largescale collection, processing, storage, and dispersal of eelgrass (Zostera marina) seeds. Restor Ecol 18:514-526

Marion SR, Orth RJ (2010b) Factors influencing seedling establishment rates in eelgrass (Zostera marina) and their implications for seagrass restoration. Restor Ecol 18: 549-559

Marion SR, Orth RJ (2012) Seedling establishment in eelgrass: seed burial effects on winter losses of developing seedlings. Mar Ecol Prog Ser 448:197-207

McGlathery KJ, Reynolds LK, Cole LW, Orth RJ, Marion SR, Schwarzschild A (2012) Recovery trajectories during state change from bare sediment to eelgrass dominance. Mar Ecol Prog Ser 448:209-221

Moore KA (2004) Influence of seagrasses on water quality in shallow regions of the lower Chesapeake Bay. J Coast Res SI45:162-178

> Moore KA, Orth RJ, Nowak JF (1993) Environmental regulation of seed germination in Zostera marina L. (eelgrass) in Chesapeake Bay: effects of light, oxygen and sediment burial. Aquat Bot 45:79-91

Moore KA, Neckles HA, Orth RJ (1996) Zostera marina (eelgrass) growth and survival along a gradient of nutrients and turbidity in the lower Chesapeake Bay. Mar Ecol Prog Ser 142:247-259

> Neckles HA, Short FT, Barker S, Kopp BS (2005) Disturbance of eelgrass Zostera marina by commercial mussel Mytilus edulis harvesting in Maine: dragging impacts and habitat recovery. Mar Ecol Prog Ser 285:57-73

Oertel GF (2001) Hypsographic, hydro-hypsographic and hydrological analysis of coastal bay environments, Great Machipongo Bay, Virginia. J Coast Res 17:775-783

- Olesen B (1999) Reproduction in Danish eelgrass (Zostera marina L.) stands: size-dependence and biomass partitioning. Aquat Bot 65:209-219

> Orth RJ, Moore KA (1983) Chesapeake Bay: an unprecedented decline in submerged aquatic vegetation. Science 222:51-53

Orth RJ, Moore KA (1984) Distribution and abundance of submerged aquatic vegetation in Chesapeake Bay: an historical perspective. Estuaries 7:531-540

> Orth RJ, Luckenbach MW, Moore KA (1994) Seed dispersal in a marine macrophyte: implications for colonization and restoration. Ecology 75:1927-1939

> Orth RJ, Fishman JR, Harwell MC, Marion SR (2003) Seed density effects on germination and initial seedling establishment in eelgrass Zostera marina in the Chesapeake Bay region. Mar Ecol Prog Ser 250:71-79

Orth RJ, Carruthers TJB, Dennison WC, Duarte CM and others (2006a) A global crisis for seagrass ecosystems. Bioscience 56:987-996

> Orth RJ, Luckenbach ML, Marion SR, Moore KA, Wilcox DJ (2006b) Seagrass recovery in the Delmarva Coastal Bays, USA. Aquat Bot 84:26-36

Orth RJ, Bieri J, Fishman JR, Harwell MC and others (2006c) A review of techniques using adult plants and seeds to transplant eelgrass Zostera marina L. in Chesapeake Bay and the Virginia coastal bays. In: Treat SF, Lewis RR (eds) Proc Conf Seagrass restoration: success, failure, and the costs of both. March 11, 2003, Sarasota, FL, p 1-17
Orth RJ, Wilcox DJ, Nagey LS, Owens AL, Whiting JR, Kenne AK (2010) Distribution of submerged aquatic vegetation in the Chesapeake Bay and coastal bays - 2009. VIMS Special Scientific Report Number 149. Final report to U.S. EPA Chesapeake Bay Program, Annapolis, MD

Paerl HW, Christian RR, Bales JD, Peierls BL, Hall NS, Joyner AR, Riggs SR (2010) Assessing the response of the Pamlico Sound, North Carolina, USA, to human and climatic disturbances: management implications. In: Kennish MJ, Paerl HW (eds) Coastal lagoons: critical habitats of environmental change. CRC Press, New York, NY, p 17-42

Paling EI, Fonseca M, van Katwijk MM, van Keulen M (2009) Seagrass restoration. In: Perillo GME, Wolanski E, Cahoon DR, Brinson M (eds) Coastal wetlands: an integrated ecosystems approach. Elsevier, Amsterdam, p 687-713

> Peterson CH, Lipcius RN (2003) Conceptual progress towards predicting quantitative ecosystem benefits of ecological restorations. Mar Ecol Prog Ser 264:297-307

Pickerell CH, Schott S, Wyllie-Echeverria S (2005) Buoy deployed seeding: demonstration of a new eelgrass (Zostera marina L.) planting method. Ecol Eng 25:127-136

Plus M, Deslous-Paoli JM, Dagault F (2003) Seagrass (Zostera marina L.) bed recolonization after anoxiainduced full mortality. Aquat Bot 77:121-134

Pokorny KS (1967) Labyrinthula. J Protozool 14:697-708

Reynolds LK, Waycott M, McGlathery KJ, Orth RJ, Zieman JC (2012) Eelgrass restoration by seed maintains genetic diversity: case study from a coastal bay system. Mar Ecol Prog Ser 448:223-233

Rasmussen E (1977) The wasting disease of eelgrass (Zostera marina) and its effects on environmental factors and fauna. In: McRoy CP, Helfferich C (eds) Seagrass ecosystems. Marcel Dekker, New York, NY, p 1-51

Setchell WA (1929) Morphological and phenological notes on Zostera marina L. Univ Calif Publ Bot 14:389-452

- Shoaf WT, Lium BW (1976) Improved extraction of chlorophyll $a$ and $b$ from algae using dimethyl sulfoxide. Limnol Oceanogr 21:926-928

Siegel S, Castellan NJ (1988) Nonparametric statistics for the behavioral sciences, 2nd edn. McGraw-Hill, New York, NY

> Stanhope JW, Anderson IC, Reay WC (2009) Base flow nutrient discharges from lower Delmarva Peninsula watersheds of Virginia, USA. J Environ Qual 38:2070-2083

Thayer GH, Stuart HH (1974) The bay scallop makes its bed of seagrass. Mar Fish Rev 36:27-30

Valdemarsen T, Canal-Verges P, Kristensen E, Holmer M, Kristiansen MD, Flindt MR (2010) Vulnerability of Zostera marina seedlings to physical stress. Mar Ecol Prog Ser 418:119-130

van der Heide T, van Nes EH, van Katwijk MM, Olff H, Smolders AJP (2011) Positive feedbacks in seagrass ecosystems - evidence from large-scale empirical data. PLoS ONE 6:e16504

> Ward LG, Kemp WM, Boynton WR (1984) The influence of waves and seagrass communities on suspended sediment dynamics in an estuarine embayment. Mar Geol 59: 85-103

- Waycott M, Duarte CM, Carruthers TJB, Orth RJ and others (2009) Accelerating loss of seagrasses across the globe threatens coastal ecosystems. Proc Natl Acad Sci USA 106:12377-12381

Wilcox DJ, Harwell MC, Orth RJ (2000) Modelling dynamic polygon objects in space and time: a new graph-based technique. Cartogr Geog Inf Sci 27:153-164

- Williams SL (1988) Disturbance and recovery of a deepwater Caribbean seagrass bed. Mar Ecol Prog Ser 42: $63-71$ 